\title{
Community-onset sepsis and its public health burden: a systematic review
}

\author{
Alexander Tsertsvadze ${ }^{*}$, Pam Royle$^{1}$, Farah Seedat ${ }^{2}$, Jennifer Cooper ${ }^{2}$, Rebecca Crosby ${ }^{2}$ and Noel McCarthy ${ }^{1,3}$
}

\begin{abstract}
Background: Sepsis is a life-threatening condition and major contributor to public health and economic burden in the industrialised world. The difficulties in accurate diagnosis lead to great variability in estimates of sepsis incidence. There has been even greater uncertainty regarding the incidence of and risk factors for community-onset sepsis (COS). We systematically reviewed the recent evidence on the incidence and risk factors of COS in high income countries (North America, Australasia, and North/Western Europe).

Methods: Cohort and case-control studies were eligible for inclusion. Medline and Embase databases were searched from 2002 onwards. References of relevant publications were hand-searched. Two reviewers screened titles/abstracts and full-texts independently. One reviewer extracted data and appraised studies which were cross-checked by independent reviewers. Disagreements were resolved via consensus. Odds ratios (ORs) and 95 percent confidence intervals ( $95 \% \mathrm{Cls}$ ) were ascertained by type of sepsis (non-severe, severe, and septic shock).

Results: Ten cohort and 4 case-control studies were included. There was a wide variation in the incidence (\# cases per 100,000 per year) of non-severe sepsis (range: 64-514), severe sepsis (range: 40-455), and septic shock (range: 9-31). Heterogeneity precluded statistical pooling. Two cohort and 4 case-control studies reported risk factors for sepsis. In one case-control and one cohort study, older age and diabetes were associated with increased risk of sepsis. The same case-control study showed an excess risk for sepsis in participants with clinical conditions (e.g., immunosuppression, lung disease, and peripheral artery disease). In one cohort study, higher risk of sepsis was associated with being a nursing home resident $(\mathrm{OR}=2.60,95 \% \mathrm{Cl}: 1.20,5.60)$ and in the other cohort study with being physically inactive $(\mathrm{OR}=1.33,95 \% \mathrm{Cl}: 1.13,1.56)$ and smoking tobacco $(\mathrm{OR}=1.85,95 \% \mathrm{Cl}: 1.54,2.22)$. The evidence on sex, ethnicity, statin use, and body mass index as risk factors was inconclusive.

Conclusions: The lack of a valid standard approach for defining sepsis makes it difficult to determine the true incidence of COS. Differences in case ascertainment contribute to the variation in incidence of COS. The evidence on $\operatorname{COS}$ is limited in terms of the number and quality of studies. This review highlights the urgent need for an accurate and standard method for identifying sepsis. Future studies need to improve the methodological shortcomings of previous research in terms of case definition, identification, and surveillance practice.
\end{abstract}

Systematic review registration: PROSPERO CRD42015023484

Keywords: Community-onset sepsis, Risk factors, Incidence of sepsis or severe sepsis

\footnotetext{
* Correspondence: a.tsertsvadze.1@warwick.ac.uk

${ }^{1}$ Communicable Disease Control Epidemiology and Evidence; Populations,

Evidence and Technologies, Division of Health Sciences, Warwick Medical

School, University of Warwick, Coventry CV4 7AL, UK

Full list of author information is available at the end of the article
} 


\section{Background}

\section{Health and economic burden}

Sepsis is a complex life-threatening condition characterised by the host's systemic inflammatory immune response to infection, which may lead to organ damage, organ failure, septic shock, and death [1]. Sepsis with its associated complications remains a major public health and economic burden in the industrialised world [2]. Outcomes of sepsis may have serious short- or long-term consequences such as amputation, damage to organs, or cognitive dysfunction. In the US, treatment of a patient with sepsis may cost up to $\$ 50,000$, translating to an annual nationwide economic burden of $\$ 17$ billion [3, 4]. In European studies, the treatment of severe sepsis in 2002 was estimated to cost approximately $£ 25,000$ [5]. Assuming an incidence of 100,000 new cases per year, the UK's National Health Service (NHS) expenditure for treating these cases would amount to $£ 2.5$ billion annually [6].

Estimates of sepsis incidence vary, which may be due to the lack of a uniform definition, disease heterogeneity, and differences in data sources/case ascertainment (e.g., clinical registries, hospital discharge databases, or vital statistics records) [4]. Large nation-wide cohort studies conducted in five high-income countries (the UK, the USA, Australia, France, and New Zealand) [3, 4, 7-9], showed a wide variation in the annual incidence of severe sepsis ranging from 51 [7] to 300 [3] cases per 100,000 population.

Furthermore, the evidence accumulated over the past two decades has shown a gradual increase (8 \%-13 \% per year) in the incidence of sepsis in high-income countries (the UK, the USA) [4, 10-12]. This trend could be due to the effects of aging populations (e.g., higher proportions of elderly, type-II diabetes, cancer) and improvements in the methods of detection $[13,14]$.

\section{Definition and diagnosis}

The current definition of sepsis introduced in 1991 [15] and updated in 2001 [1] encompasses the presence of infection and more than one of the Systemic Inflammatory Response Syndrome (SIRS) criteria including: a) body temperature $\left[>38{ }^{\circ} \mathrm{C}\right.$ or $<36{ }^{\circ} \mathrm{C}$ ], b) heart rate [ $>90$ beats/ min], c) hyper-ventilation [respiratory rate $>20$ breaths/ min or $\mathrm{PaCo} 2<32 \mathrm{mmHg}$, and d) White Blood Cell Count $[>12,000$ cells $/ \mu \mathrm{L}$ or $<4,000$ cells $/ \mu \mathrm{L}]$. According to this definition, sepsis with organ dysfunction and sepsis with acute circulatory failure with arterial hypotension have been termed as severe sepsis and septic shock, respectively [1]. The utility of joint infection and SIRS criteria as a diagnostic tool is limited owing to its high sensitivity and low specificity $[10,16]$. Some authors have suggested that this definition should additionally incorporate a more specific sign of sepsis that provides evidence of organ dysfunction [13, 14].
The variation in case definition complicates the comparison of findings across studies.

\section{Community-onset sepsis}

Depending on the place of acquisition, sepsis is classified into community-onset and hospital-acquired (i.e., nosocomial) infection [17]. The two contexts of sepsis acquisition differ in the host characteristics (e.g., demographics, risk profile, resistance patterns), pathogens, and outcomes [18-21]. The definition of community-onset sepsis (COS) in the literature has not been consistent [22]. One widely used definition of COS is the presence of positive blood culture and SIRS criteria before or within 48 hours of hospital admission [19, 21, 23-25]. The majority of studies have not attempted to distinguish between COS and hospital-acquired sepsis. This is an important evidencebased gap for planning public facing interventions.

In this systematic review, we aimed to synthesise the recent evidence on the incidence and risk factors of COS in the western industrialised world (North America, Australasia, and North/Western Europe). This independent review was undertaken to provide evidence for Public Health England (PHE). Motivation for estimating the overall burden and risk factors of COS was to contribute information for community-based interventions to guide patients and the public in health-care seeking behaviour.

\section{Methods}

This review was conducted based on the previously published protocol [26]. The modification of quality assessment strategy was the only deviation from the methodology described in the protocol. This review is reported according to the recommendations from the Preferred Reporting Items for Systematic Review and Meta-Analysis (PRISMA) statement. The corresponding PRISMA checklist is provided as an Additional file 1 [27].

The review focused on the evidence from countries located in North America, Australasia, and North/Western Europe. Given the longitudinal changes in the incidence, modifications in the definition [10] and introduction of ICD-9 coding of sepsis [28], we restricted our focus to studies providing data that had been collected in 2002 or onwards.

\section{Study inclusion criteria}

English-language full-text reports of cohort and casecontrol studies reporting incidence of and/or risk factors for COS were included.

- Study setting: population- or hospital-based studies considering COS separately

- Population: community dwellers, hospitalised patients (male/female) of any age (except for 
neonates) from a defined population with or without COS at study baseline. The study used relevant ICD-9/10 codes $[3,4]$ and established criteria for the diagnosis of sepsis [1].

- Exposure/risk factor: any patient characteristic or clinical parameter (e.g., age, sex, co-morbidity, heart rate, body temperature) associated with a risk of COS

- Outcome: annual incidence (per population/hospital admission) of COS; risk factors for COS.

We excluded studies of nosocomial sepsis and those unable to differentiate COS; intervention and prognostic studies; studies reporting only single-site infection or single infecting species; and studies limited to specific subgroups (e.g., neonates) or clinical conditions (e.g., cancer, coronary heart disease).

\section{Search strategy}

We searched Medline and Embase from 01 January, 2002 to May 8, 2015, using a combination of subject headings and keywords for sepsis and related terms combined with terms for epidemiology and community based settings.

We searched for unpublished literature through the following sources: a) hand search of reference lists, b) relevant websites of organizations dealing with sepsis (International Sepsis Forum, Sepsis Trust UK, Sepsis Alliance, Centre for Disease Control, World Sepsis Day), c) contacting experts in the field, d) theses database (index to theses), and e) Google Scholar (government or other reports). We did not search abstracts from conference proceedings, since they do not have full texts and therefore do not provide sufficient information to verify a) how sepsis was diagnosed, b) whether study population had COS or other sepsis, and c) details on incidence and risk factors. The Medline and Embase search strategies are provided in Additional file 2.

\section{Study selection}

All bibliographic records identified were compiled and de-duplicated in an endnote database. Two independent reviewers (AT and FS) using a pre-defined piloted form screened all titles/abstracts and later full text reports of potentially eligible records. Disagreements at both levels were resolved via consensus.

\section{Data extraction}

One reviewer (AT) used a pre-piloted sheet and extracted relevant information before it was checked by two independent reviewers (JC and RC). Disagreements between the reviewers were resolved via consensus. The extracted data included information on study (e.g., author name, year of publication, country of conduct, design, study setting, sample size), risk factors (e.g., socio-demographic characteristics, co-morbidities, clinical symptom or parameter), and outcomes (e.g., definition of sepsis, type of pathogen, incidence). Missing statistical parameters of importance were calculated, if data permitted. The data extraction sheet is provided in Additional file 3.

\section{Quality assessment}

Methodological quality of studies was appraised by one reviewer (AT) and checked independently by another reviewer (JC). The assessments were done using two checklists by the Scottish Intercollegiate Guidelines Network (SIGN) for cohort [29] and case-control studies [30]. We selected these tools based on the guidance for evidence-based decision making in infectious diseases epidemiology, prevention, and control proposed by Harder and colleagues [31].

Both checklists address five sources of bias: study research question, participant selection, information bias, confounding, statistical analysis, and an overall assessment of the study (i.e., summary judgement on internal and external validity). The overall quality ratings (high, acceptable, or low) were based on the extent to which the pre-selected important domains of bias were affected in cohort (Selection of subjects: items 4-5; Assessment: items 7, 10-11; Confounding: item 13) and case-control studies (Selection of subjects: items 3-4, 6-7; Assessment: item 9; Confounding: item 10). The checklists and assessments are provided in Additional file 4.

\section{Data analysis and synthesis}

The evidence was synthesized and organised in summary tables and text. The incidence and risk factor data were stratified by study design and sepsis severity: non-severe, severe, and septic shock. The overall sepsis incidence was expressed as the annual number of new cases per population, cumulative incidence proportion (CIP; in \%) or incidence density rate (IDR). The association between risk factors and sepsis was expressed with odds ratios (ORs) and hazard rate ratios (HRRs) with 95 percent confidence intervals (95\% CIs).

Meta-analysis could not be performed due to extensive heterogeneity across study population characteristics, exposure definitions, and the outcome measurement methodology. The scarcity of evidence did not permit to determine the effects of publication bias and the conduct of sub-group analysis by age, sex, study setting, and place of acquisition (community-acquired vs. healthcareassociated community onset).

\section{Results}

Literature search and included studies

All the searches (electronic databases, hand search, contacting authors, and auto alerts) identified 6,351 
bibliographic records. No additional records were found through the websites of sepsis organizations, theses database, and Google Scholar.

After duplicates were removed, a total of 4,305 titles/ abstracts were screened, of which 275 passed to full text screening level. Of the 275 full text reports examined, only 22 met the inclusion criteria (representing 14 studies) [11,32-52]. The study selection process and reasons for exclusion at the full-text screening level are presented in Fig. 1 (the PRISMA Flow Diagram) [27].

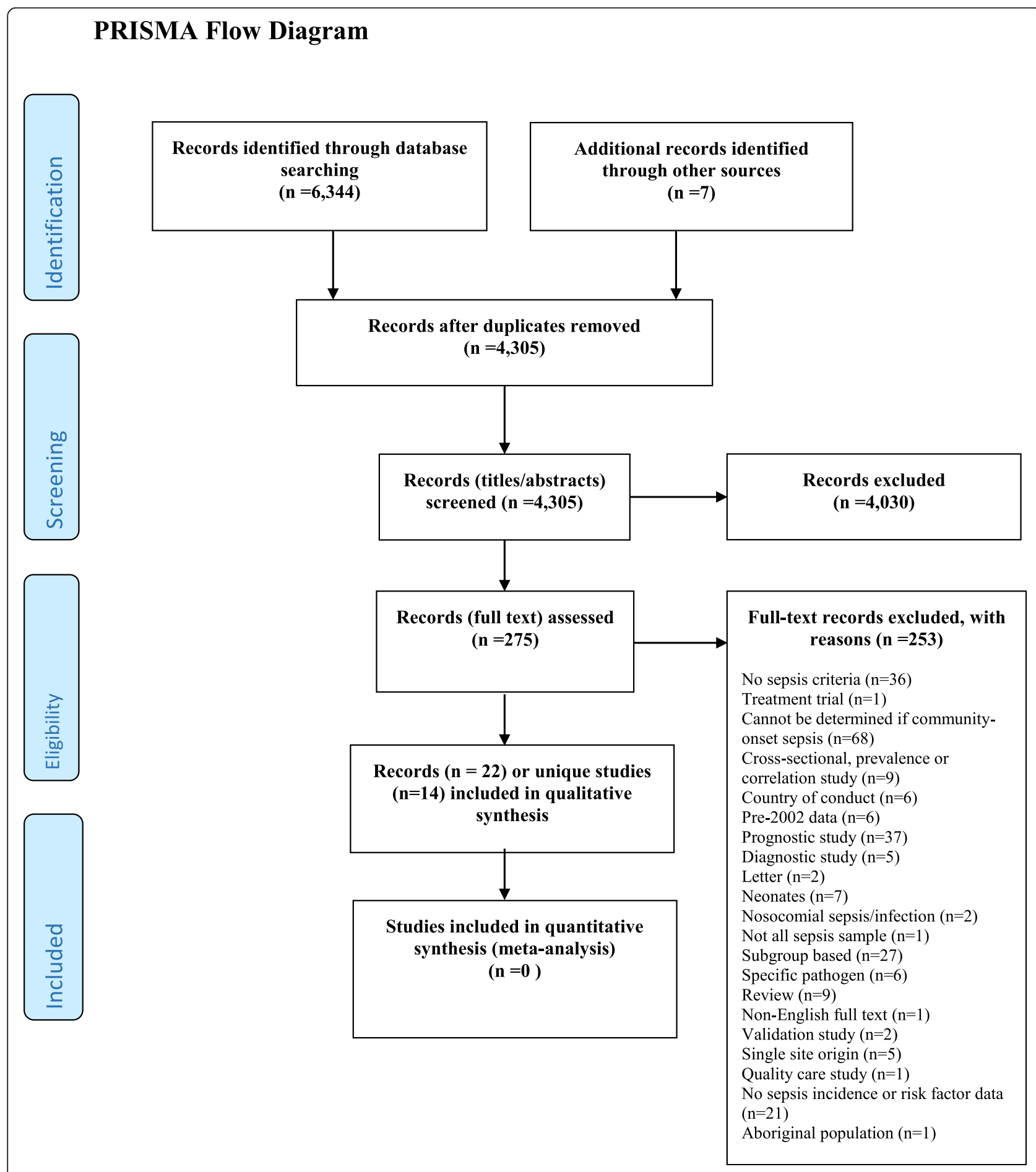

Fig. 1 PRISMA Flow Diagram 
Of the 14 included studies, 10 were cohort studies $[11,32-38,40-42,46-52]$ and 4 case-control studies [39, 43-45].

One cohort study, which was supported by 9 publications [32-38, 40, 41], used the data from the Reasons for Geographic And Racial Differences in Stroke (REGARDS) study database [53]. In this review, this cohort study is referred as the REGARDS-sepsis cohort study and as a whole it is referenced as Wang et al. 2012 [36]. Two case-control studies by Wang et al. [39] and Henriksen et al. [43] were based on the data from the REGARDS-sepsis study [36] and the cohort study by Henriksen et al. [42], respectively. Although based on the same cohort data, these two case-control studies have been treated as distinct entities from their cohort study counterparts in the data synthesis because of the different design and outcomes reported (i.e., no overlap or double-counting of studies per outcome). The Wang et al. case-control study [39] is referred to as the REGARDS-sepsis case-control study.

\section{Study and population characteristics}

Study population characteristics for the included studies are provided in Table 1 (cohort studies) and Table 2 (case-control studies).

\section{Cohort studies}

Of the 10 cohort studies, 4 were of prospective [36, 42, $46,49]$ and 6 were of retrospective design $[11,47,48$, 50-52].

In most studies, the settings were emergency departments, intensive care units, high dependence units, and hospital wards. The geographic scope of catchment area varied from nationwide [11, 36, 47, 48, 50, 52] to regional [51] or municipal [42, 46, 49]. The length of follow-up ranged from 4 months [46] to 10 years $[36,51]$.

Studies enrolled cohorts of patients hospitalised, admitted, or visiting ED/ICU for different reasons (e.g., medical, surgery, trauma, or infection) [11, 42, 46-50, 52]. The REGARDS-sepsis cohort study was the only study with a well-defined study-base sample which consisted of community-dwelling people who were sepsis-free at the study baseline [36]. The population in the REGARDS-sepsis cohort study included those aged 45 years or older [36].

The majority of studies used the standard consensusbased criteria for non-severe and severe sepsis as outlined by Levy et al. [1]. Only 5 studies reported definitions of COS explicitly (i.e., sepsis manifested within the first 24-48 hours of admission) [11, 36, 42, 49, 50].

Data sources utilised were administrative databases ranging from clinical records $[11,36,42,46,49,52]$ to hospital discharge records $[47,48,50]$. One study used an emergency medical services encounters database linked with hospital discharge records [51].

\section{Case-control studies}

This review included 4 case-control studies [39, 43-45]. The REGARDS-sepsis case-control study [39], analysed only a subset of 162 case-control matched pairs sampled from the REGARDS-sepsis cohort study. In contrast, Henriksen et al. [43], analysed all sepsis cases $(n=1,713)$ and controls ( $\mathrm{n}=227,054$; residents not hospitalised up to 7 days before the index date) from the cohort study base [42]. The study by Jovanovich et al. [44] investigated 211 matched case-control pairs admitted to tertiary care centres, small clinics, and hospitals. Legras and colleagues [45], analysed 211 matched case-control (mild bacterial infection) pairs admitted to intensive care units or hospital wards. The sepsis definitions used were based on the standard criteria [1] and ICD-9 codes (995.91, 995.92).

\section{Quality of included studies}

Methodological quality assessments are presented in Additional file 4 (Table S1: cohort studies and Table S2: case-control studies).

\section{Cohort studies}

Of the 10 cohort studies, only 4 were rated as of acceptable quality $[11,36,42,46]$. The 6 remaining studies were judged to be of low quality [47-52]. Poor reporting (item response: can't say) for the absence of outcome at baseline (item 4) and the validity of methods for the outcome assessment (item 11) were main contributory factors for the cohort studies judged to be of low quality. Also, it was not clear how comparable the exposure groups in these studies were. Three cohort studies with acceptable quality were of prospective design and described explicitly defined populations free of sepsis at baseline (i.e., denominators) [36, 42, 46].

\section{Case-control studies}

All 4 case-control studies were of low quality [39, 43-45]. Specifically, the controls in three studies were cases hospitalised for serious infection (item 7) [39], mild bacterial infection [45], or non-specified medical condition [44]. Only one study utilised true non-cases as controls [43]. It was not clear if the same exclusion criteria was applied to both cases and controls for two studies [43, 44] and how valid the exposure measurement was in two studies [43, 45].

\section{Review outcomes} Incidence of COS

Data on the incidence of COS is provided in Table 3. 
Table 1 Study and population characteristics: cohort studies

\begin{tabular}{|c|c|c|c|c|}
\hline $\begin{array}{l}\text { Study ID year } \\
\text { [country] }\end{array}$ & $\begin{array}{l}\text { Study } \\
\text { characteristics }\end{array}$ & Population characteristics & Case identification and data source & Exposure and follow-up \\
\hline \multirow[t]{4}{*}{$\begin{array}{l}\text { Esteban } 2007 \\
\text { [46] Spain }\end{array}$} & $\begin{array}{l}\text { Design: } \\
\text { prospective }\end{array}$ & $\begin{array}{l}\text { Case definition and criteria used: } \\
\text { ACCP/SCCM definitions }{ }^{\mu}\end{array}$ & \multirow[t]{4}{*}{ Case report forms } & Exposure: Not defined \\
\hline & $\begin{array}{l}\text { Study setting: } \\
\text { ICU, hospital ward }\end{array}$ & $\begin{array}{l}\text { Criteria for COS: } 83 \% \text { sepsis patients } \\
\text { had a community-acquired infection } \\
\text { (no other details given) }\end{array}$ & & $\begin{array}{l}\text { FU: March 1, } 2003 \text { to June } \\
\text { 30, } 2003\end{array}$ \\
\hline & $\begin{array}{l}\text { Geographic } \\
\text { scope: city/ } \\
\text { municipal }\end{array}$ & $\begin{array}{l}\text { Inclusion criteria: Consecutively } \\
\text { admitted patients (age } \geq 18 \text { years) }\end{array}$ & & FU duration: 4 months \\
\hline & $\begin{array}{l}\text { Recruitment } \\
\text { years: March 1, } \\
2003 \text { to June 30, } \\
2003\end{array}$ & $\begin{array}{l}\text { Description ( } \mathbf{n} \text { sample size): 15,852 } \\
\text { (includes } n=702 \text { non-severe sepsis } \\
\text { cases) }\end{array}$ & & \\
\hline \multirow[t]{5}{*}{$\begin{array}{l}\text { Ginde } 2013 \\
\text { [47] The USA }\end{array}$} & $\begin{array}{l}\text { Design: } \\
\text { retrospective }\end{array}$ & \multirow{2}{*}{$\begin{array}{l}\text { Case definition and criteria used: } \\
\text { Severe sepsis as concurrent bacterial or } \\
\text { fungal infection plus acute organ } \\
\text { dysfunction using ICD-9-CM codes } \\
\text { (995.92) for infection and acute organ } \\
\text { dysfunction }\end{array}$} & \multirow{3}{*}{$\begin{array}{l}\text { Annual survey of ED visits conducted } \\
\text { by the National Centre for Health } \\
\text { Statistics (associated with U.S. non- } \\
\text { institutional, general and short stay } \\
\text { hospitals) }\end{array}$} & $\begin{array}{l}\text { Exposure: Age, nursing } \\
\text { home residence }\end{array}$ \\
\hline & \multirow[t]{2}{*}{$\begin{array}{l}\text { Study setting: } \\
\text { nursing residence, } \\
\text { community-living, } \\
\text { ED }\end{array}$} & & & FU: 2005 to 2009 \\
\hline & & $\begin{array}{l}\text { Criteria for COS: patients admitted to } \\
\text { ED for severe sepsis }\end{array}$ & & FU duration: 5 years \\
\hline & $\begin{array}{l}\text { Geographic } \\
\text { scope: } \\
\text { Nationwide }\end{array}$ & $\begin{array}{l}\text { Inclusion criteria: adults ( } \geq 18 \text { years) } \\
\text { who visited ED (with or without } \\
\text { infection other than sepsis) }\end{array}$ & & \\
\hline & $\begin{array}{l}\text { Recruitment } \\
\text { years: } 2005-2009\end{array}$ & $\begin{array}{l}\text { Description (n sample size): a } \\
\text { nationally representative survey of all }\end{array}$ & & \\
\hline
\end{tabular}

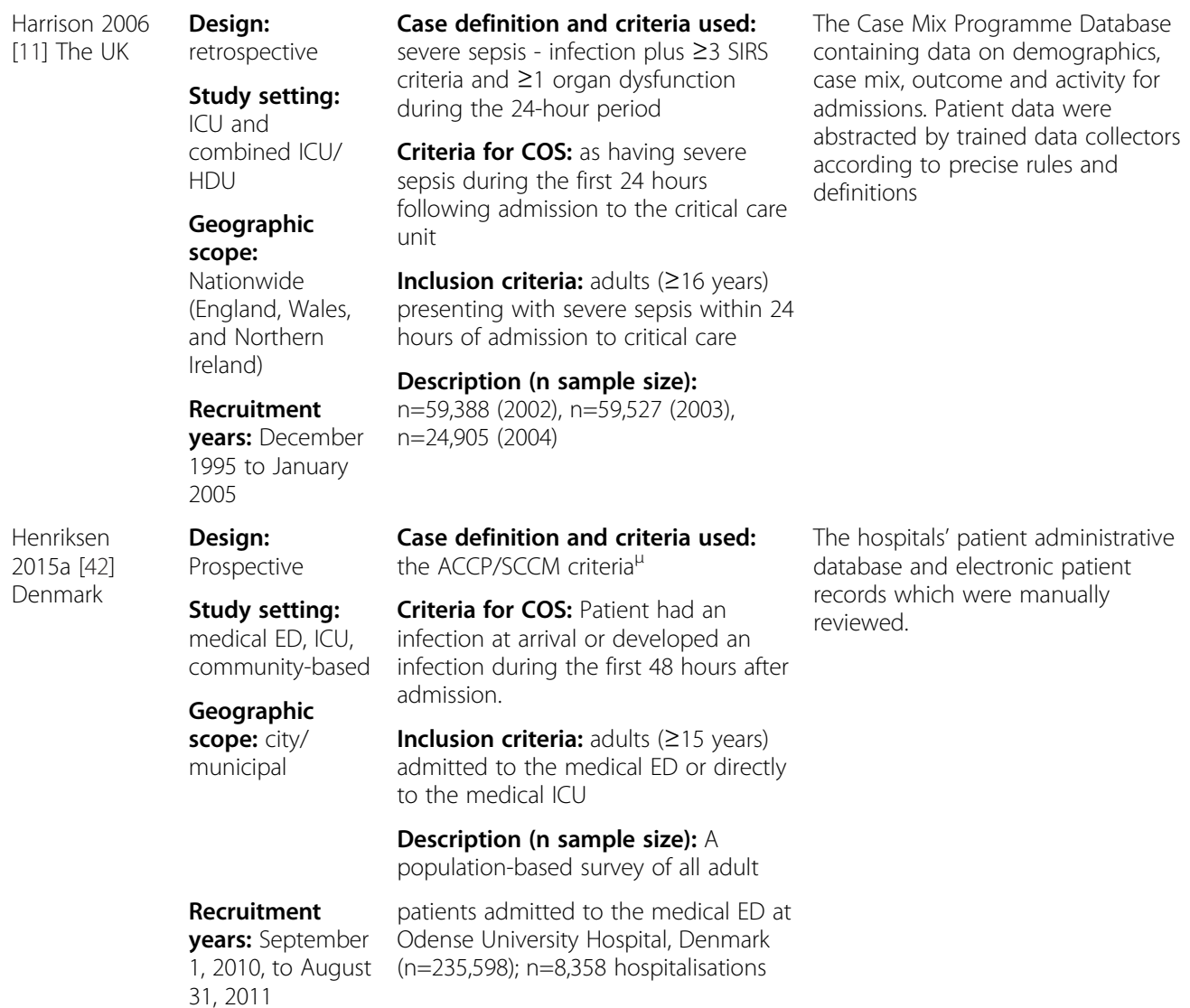

Exposure: not defined

FU: December 2001 to January 2005

FU duration: 2 years (20022004)

Exposure: age, sex

FU: September 1, 2010 to August 31, 2011

FU duration: 12 months 
Table 1 Study and population characteristics: cohort studies (Continued)

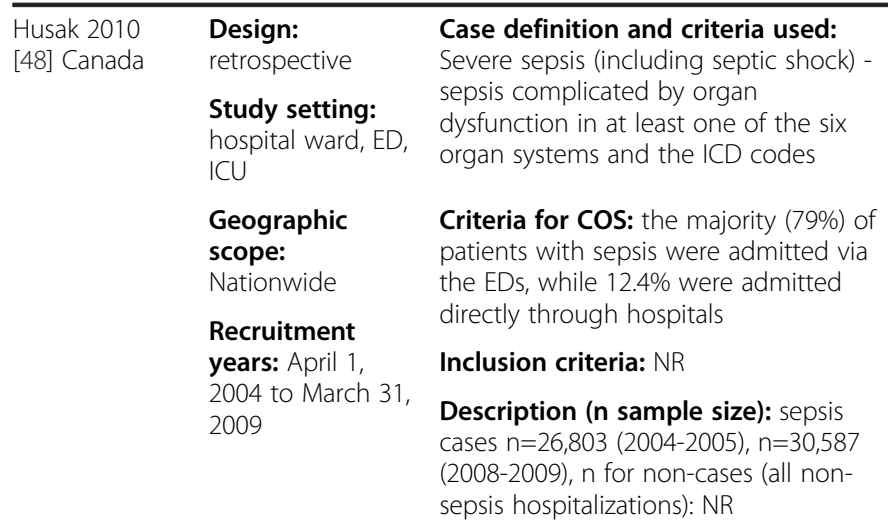

Nygard 2014 Design:

[49] Norway prospective

\section{Study setting:}

ED, ICU, HDU, and

Page 2015 [50] Design: The USA

Wang 2012 [36] Design:

REGARDS-

sepsis cohort

study The USA sepsis cases; non-cases (n): 350,000

Hospital discharge abstract database

Exposure: Not defined

FU: April 1, 2004 to March

31, 2009

FU duration: 5 years

Clinical data were registered prospectively until hospital discharge or in-hospital death using predefined case report forms. Information was collected from medical records, patient charts, and the intensive care electronic monitoring system
Exposure: not defined

FU: January 2008 to December 2008

FU duration: 12 months combined ICU/ HDU

\section{Geographic scope: city/ municipal}

Recruitment years: January 2008 - December 2008 prospective

severe sepsis within 24 hours of admission to the primary institution

Inclusion criteria: patients $>15$ years of age hospitalized due to COS, including patients transferred from affiliated hospitals, if they developed severe sepsis within 24 hours of admission to the primary institution

Description (n sample size): total N hospitalisations (NR); $n=220$ severe population

Case definition and criteria used: severe sepsis was defined using the

Study setting: NR $\begin{aligned} & \text { methodology of Angus et al. } \\ & \text { identifying hospitalizations with the }\end{aligned}$

Geographic

scope:

Nationwide

Recruitment years: January to December 2012 presence of ICD-9 discharge diagnose for both a serious infection and organ dysfunction

Criteria for COS: Hospitalizations with an infection present at admission were subdivided into healthcare-associated (admitted from nursing facility, receiving home healthcare, or were on haemodialysis prior to admission), community acquired (from the community). Those discharged without infections at admission were categorized as hospital-acquired

Inclusion criteria: all hospital discharges from January 1, 2012 to December 31, 2012

Description (n sample size): $n=3,355,753$ hospitalisations; non-cases $\mathrm{n}$ (population) $=\mathrm{NR}$

Case definition and criteria used: An Structured interviews, in-home visits, infection plus $\geq 2$ SIRS criteria $^{\mu}$

Study setting:

Criteria for COS: cohort of Community-based, community-dwelling individuals. The hospital ward, ED
Hospital discharge data from the UHC representing 300 academic and community hospitals across 42 states. Using medical record review, coders assigned discharge diagnoses for each hospitalization lab results, monitoring every 6 months, medical and hospital admission records (clinical and lab data) study focused on individuals presenting to the hospital or ED with community-acquired sepsis

\section{Exposure: not defined}

FU: January 1, 2012 to December 31, 2012

FU duration: 12 months
Exposure: anthropometric socio-demographic, dietary, and life-style factors, chronic conditions, and statin use 
Table 1 Study and population characteristics: cohort studies (Continued)

\begin{tabular}{|c|c|c|c|c|}
\hline & Geographic & \multicolumn{3}{|l|}{ Inclusion criteria: NR } \\
\hline & $\begin{array}{l}\text { scope: } \\
\text { Nationwide }\end{array}$ & \multirow{2}{*}{$\begin{array}{l}\text { Description ( } \mathbf{n} \text { sample size): } \\
\text { Community-dwelling } \geq 45 \text { years old } \\
\text { individuals in the US }(n=30,239)\end{array}$} & & $\begin{array}{l}\text { FU: } 5 \text { February, } 2003 \text { to } 31 \\
\text { December, } 2012\end{array}$ \\
\hline & $\begin{array}{l}\text { Recruitment } \\
\text { years: 2003-2007 }\end{array}$ & & & FU duration: $\geq 7$ years \\
\hline \multirow[t]{5}{*}{$\begin{array}{l}\text { Seymour } 2012 \\
\text { [51] The USA }\end{array}$} & $\begin{array}{l}\text { Design: } \\
\text { retrospective }\end{array}$ & \multirow{3}{*}{$\begin{array}{l}\text { Case definition and criteria used: } \\
\text { Hospitalization with severe sepsis using } \\
\text { the ICD-9-CM (995.92 and 785.52). } \\
\text { Criteria for COS: pre-hospital severe } \\
\text { sepsis }\end{array}$} & \multirow{5}{*}{$\begin{array}{l}\text { EMS reports computerized database } \\
\text { including dispatch, demographic, } \\
\text { clinical, and transport data for each } \\
\text { incident. EMS data were linked to } \\
\text { hospital discharge records }\end{array}$} & Exposure: not defined \\
\hline & \multirow{2}{*}{$\begin{array}{l}\text { Study setting: } \\
\text { pre-hospital EMS }\end{array}$} & & & FU: 2000 to 2009 \\
\hline & & & & FU duration: 10 years \\
\hline & $\begin{array}{l}\text { Geographic } \\
\text { scope: regional } \\
\text { (King County in } \\
\text { Washington State) }\end{array}$ & \multicolumn{2}{|l|}{$\begin{array}{l}\text { Inclusion criteria: all adult EMS } \\
\text { encounters involving non-trauma, } \\
\text { non-cardiac arrest patients transported } \\
\text { from a scene to a receiving hospital by } \\
\text { ground ambulance }\end{array}$} & \\
\hline & $\begin{array}{l}\text { Recruitment } \\
\text { years: } 2000-2009\end{array}$ & \multicolumn{2}{|l|}{$\begin{array}{l}\text { Description ( } \mathbf{n} \text { sample size): all 2000- } \\
2009 \text { EMS encounters in the area of } 1.2 \\
\text { million residents }(n=407,176)\end{array}$} & \\
\hline \multirow[t]{6}{*}{$\begin{array}{l}\text { Wang } 2007 \text { [52] } \\
\text { The USA }\end{array}$} & $\begin{array}{l}\text { Design: } \\
\text { retrospective }\end{array}$ & \multirow{3}{*}{$\begin{array}{l}\text { Case definition and criteria used: } \\
\text { the criteria by ACCP/SCCM }{ }^{\mu} \text { and } \\
\text { SCCM/ESICM/ACCP/ATS/SIS; ICD-9 } \\
\text { codes } 990.90 \text { and } 995.92 \text { as sepsis and } \\
\text { severe sepsis, respectively }\end{array}$} & \multirow{6}{*}{$\begin{array}{l}\text { The study used the } 2001-2004 \\
\text { NHAMCS public use data set which is } \\
\text { a national sample of ED and } \\
\text { outpatient visits at hospitals across the } \\
\text { US }\end{array}$} & \multirow[t]{3}{*}{ Exposure: not defined } \\
\hline & & & & \\
\hline & Study setting: ED & & & \\
\hline & Geographic & \multicolumn{2}{|l|}{$\begin{array}{l}\text { Criteria for COS: patients with severe } \\
\text { sepsis presenting to ED }\end{array}$} & \\
\hline & $\begin{array}{l}\text { Recruitment } \\
\text { years: } 2001-2004\end{array}$ & \multicolumn{2}{|l|}{$\begin{array}{l}\text { Inclusion criteria: adults ( } \geq 18 \text { years) } \\
\text { presenting to EDs during 2001-2004 } \\
\text { (with or without severe sepsis) }\end{array}$} & \\
\hline & & \multicolumn{2}{|l|}{$\begin{array}{l}\text { Description ( } \mathrm{n} \text { sample size): } \\
\mathrm{n}=113,123 \mathrm{ED} \text { visits (sample-based } 4 \\
\text { years); } 4 \text {-year national estimate } \\
\mathrm{n}=331,531,000 \mathrm{ED} \text { visits; annual } \\
\text { national estimate } \mathrm{n}=82,883,000 \mathrm{ED} \\
\text { visits }\end{array}$} & \\
\hline \multicolumn{5}{|c|}{$\begin{array}{l}\text { NR not reported, COS community-onset sepsis, ICU intensive care unit, HDU high dependency unit, FU follow-up, SIRS systemic inflammatory response syndrome, } \\
\text { REGARDS Reasons for Geographic And Racial Differences in Stroke, } M I \text { myocardial infarction, CAD coronary artery disease, DVT deep vein thrombosis, ED } \\
\text { emergency department, AF atrial fibrillation, BMI body mass index, WC waist circumference, PAD peripheral artery disease, TV television, NHAMCS National Hospita } \\
\text { Ambulatory Medical Care Survey, ICD-9 CM International Classification of Disease, Ninth Revision Clinical Modification, IQR interquartile range, ACCP/SCCM } \\
\text { American College of Chest Physicians/Society of Critical Care Medicine, ESICM European Society of Intensive Care Medicine, ATS American Thoracic Society, SIS } \\
\text { Surgical Infection Society, ICD-10-CA International Statistical Classification of Diseases and Related Health Problems, 10th Revision, Canada, CCI Canadian } \\
\text { Classification of Health Interventions, EMS emergency medical services } \\
\mu \text { International Sepsis Definitions Conference }[1] \\
{ }^{3} \text { REGARDS-sepsis cohort study publications [32-38, 40,41] }\end{array}$} \\
\hline
\end{tabular}

All sepsis The incidence of all sepsis (per population) was reported in two studies [42, 48]. The study by Henriksen et al. observed 727 sepsis cases (non-severe, severe, and septic shock; 95 \% CI: 693, 762) per 100,000 population per year [42]. The incidence of all sepsis (non-severe and severe) in the study by Husak et al. was estimated to be 103 cases ( $95 \%$ CI was not reported and could not be calculated) per 100,000 population per year [48].

Non-severe sepsis The incidence of non-severe sepsis (per population) reported in 4 studies [36, 42, 46, 48] ranged from 64 (95\% CI not available) [48] to 514 (95\% CI: 489, 539) [36] cases per 100,000 population per year. Of these, two studies by Esteban et al. [46] and Henriksen et al. [42] reported the incidence of 367 (95\% CI:
$352,384)$ and 264 (95 \% CI: 243, 285) cases, respectively per 100,000 population per year.

Severe sepsis The incidence of severe sepsis (per population) was estimated and provided in 5 studies [11, 42, $46,48,49]$.

The reported estimates across 4 studies [11, 46, 48, 49] ranged from 40 (95\% CI not available) [48] to 104 (95\% CI: 96,113$)$ [46] cases per 100,000 population per year. The cohort study by Henriksen et al. reported an incidence of 455 (95\% CI: 428, 482) cases of severe sepsis per 100,000 population per year [42].

Six studies also reported the incidence of severe sepsis (per hospitalisation or ED visit) which ranged from $0.22 \%$ (95\% CI not available) [49] to $8.12 \%$ (95 \% CI: 8.10, 8.15) [50] per hospitalisation/ED visit per year. The incidence of 
Table 2 Study and population characteristics: case-control studies

\begin{tabular}{|c|c|c|}
\hline $\begin{array}{l}\text { Study ID year } \\
\text { [country] }\end{array}$ & Study characteristics & Population characteristics \\
\hline \multirow[t]{6}{*}{$\begin{array}{l}\text { Henriksen 2015b } \\
\text { [43] Denmark }\end{array}$} & $\begin{array}{l}\text { Study setting: medical } \\
E D, I C U \text {, community-based }\end{array}$ & $\begin{array}{l}\text { Case definition: sepsis (non-severe), severe sepsis, or } \\
\text { septic shock according to the ACCP/SCCM criteria. }\end{array}$ \\
\hline & $\begin{array}{l}\text { Geographic scope: city/ } \\
\text { municipal }\end{array}$ & $\begin{array}{l}\text { Control definition: all adults ( } \geq 15 \text { years) with } \\
\text { residence in the hospital catchment-area }(N=235,598) \\
\text { during the study period who had not been } \\
\text { hospitalized up to } 7 \text { days before the index date. }\end{array}$ \\
\hline & \multirow{4}{*}{$\begin{array}{l}\text { Recruitment years: } \\
\text { September 1,2010 to } \\
\text { August } 31,2011\end{array}$} & $\begin{array}{l}\text { Criteria for COS: Patient had an infection at arrival } \\
\text { within the first } 48 \text { hours after admission }\end{array}$ \\
\hline & & $\begin{array}{l}\text { Inclusion criteria (cases): All adults ( } \geq 15 \text { years) } \\
\text { admitted to the medical ICU or ED. }\end{array}$ \\
\hline & & $\begin{array}{l}\text { Inclusion criteria (controls): see controls definition } \\
\text { and criteria }\end{array}$ \\
\hline & & $\begin{array}{l}\text { Exclusion criteria: cases with a prior hospitalization up } \\
\text { to } 7 \text { days before the current admission. Patients } \\
\text { transferred from other hospitals, patients residing } \\
\text { outside the hospitals catchment-area at the time of } \\
\text { admission and patients who were unidentified } \\
\text { throughout the entire course of admission }\end{array}$ \\
\hline
\end{tabular}

Identification and data source

[country]

Henriksen 2015b Study setting: medical Case definition: sepsis (non-severe), severe sepsis, or

Data electronically extracted from the patient's records and validated by trained data. All admissions were manually reviewed. Predefined risk factors retrieved from several population-based registers during the study period who had not been and

Jovanovich 2014 [44] The USA

Legras 2009 [45] France
Study setting: tertiarylevel care centres and small clinics and hospitals

N cases: 1,713 sepsis of any severity $(n=621$ non-severe sepsis, $\mathrm{n}=1,071$ severe sepsis, and $\mathrm{n}=21$ septic shock)

N controls: 227,054

Case definition: adults hospitalized for sepsis or severe sepsis; ICD-9 codes (995.91, 995.92)

Control definition: randomly selected adult patients without sepsis diagnosis admitted within the same time period and matched 1:1 with cases by age, sex race, and season of 25(OH)D measurement

Geographic scope: InterState (Utah and Idaho)

Recruitment years: 1 January 2008 and 31

December 2010

Study setting: $I C U$, hospital ward

Geographic scope: regional

Recruitment years: February 2004 to November 2005
Criteria for COS: community-living adults

Inclusion criteria (cases): NR

Inclusion criteria (controls): NR

Exclusion criteria: NR

N cases: 211

N controls: 211

Case definition: the ACCP/SCCM criteria was used (severe sepsis or septic shock)

Control definition: Participants admitted to hospital for mild bacterial infection (without severe sepsis or septic shock)

Criteria for COS: Community-acquired (NR)

Inclusion criteria (cases): Participants $>15$ years admitted to an ICU with community-onset severe sepsis or septic shock

Inclusion criteria (controls): Participants admitted to hospital for mild bacterial community-acquired (non-sepsis) infection

Exclusion criteria: chronic kidney failure (creatinine clearance $<30 \mathrm{ml} / \mathrm{min}$ ), pregnancy, nosocomial infection, or congenital/acquired immunosuppression (defined as the presence of metastatic neoplasia, haemopathy, aplasia before the onset of sepsis), AIDS (independently of CD4+ T-cell count) and chronic administration of immunosuppressive treatments

N cases: $n=152$ ( $n=34$ sever sepsis; $n=118$ septic shock)
Medical histories and data on previous prescriptions obtained from relatives and general practitioner. NSAID use was quantified by listing all the drugs taken during the observation period, and standard interviews were conducted by physicians 
Table 2 Study and population characteristics: case-control studies (Continued)

\begin{tabular}{|c|c|c|c|}
\hline & & N controls: 152 & \\
\hline \multirow[t]{7}{*}{$\begin{array}{l}\text { Wang 2013c [39] } \\
\text { REGARDS-sepsis } \\
\text { case-control study } \\
\text { The USA }\end{array}$} & $\begin{array}{l}\text { Study setting: } \\
\text { community-based, } \\
\text { hospital, ED } \\
\text { Geographic scope: } \\
\text { Nationwide }\end{array}$ & $\begin{array}{l}\text { Case definition: laboratory confirmed infection plus } \geq \\
2 \text { SIRS criteria }\end{array}$ & \multirow[t]{7}{*}{$\begin{array}{l}\text { Structured interviews, in-home visits, lab } \\
\text { results, monitoring every } 6 \text { months, } \\
\text { medical and hospital admission records } \\
\text { (clinical and lab data); blood samples } \\
\text { collected from fasting subjects at their } \\
\text { homes }\end{array}$} \\
\hline & $\begin{array}{l}\text { Recruitment years: } \\
\text { January 2003- October } \\
2007\end{array}$ & $\begin{array}{l}\text { Criteria for COS: cohort of community-dwelling } \\
\text { individuals. Presentation to the hospital consisted of } \\
\text { the time of Emergency Department triage or admission } \\
\text { to inpatient unit (for participants admitted directly to } \\
\text { the hospital). To allow for acute changes in the } \\
\text { participant's condition during early hospitalization, we } \\
\text { used vital signs and laboratory test results for the initial } \\
28 \text { h of hospitalization. Our study focused on } \\
\text { individuals presenting to the hospital or ED with } \\
\text { community-acquired sepsis. We did not include } \\
\text { "hospital-acquired" sepsis developing at later points of } \\
\text { hospitalization }\end{array}$ & \\
\hline & & $\begin{array}{l}\text { Inclusion criteria (cases): Patients hospitalized for } \\
\text { sepsis during the observation period were eligible. }\end{array}$ & \\
\hline & & $\begin{array}{l}\text { Inclusion criteria (controls): Individuals with serious } \\
\text { infection who did not experience a hospitalization for } \\
\text { sepsis, matching for age }( \pm 5 \text { years), sex, and time } \\
\text { epoch }\end{array}$ & \\
\hline & & $\begin{array}{l}\text { Exclusion criteria: individuals hospitalized for } \\
\text { conditions unrelated to infections }\end{array}$ & \\
\hline & & N cases: 162 & \\
\hline & & N controls: 162 & \\
\hline
\end{tabular}

NR not reported, COS community-onset sepsis, SIRS systemic inflammatory response syndrome, ED emergency department, ICU intensive care unit, $A C C P / S C C M$ American College of Chest Physicians/Society of Critical Care Medicine, Gl gastrointestinal, CVD cardiovascular disease, OR odds ratio, $95 \%$ CI 95 percent confidence interval, AIDS acquired immunodeficiency syndrome, NSAID non-steroidal anti-inflammatory drugs, IL-6 interleukin-6, TNF- $a$ tumor necrosis factor alpha, ICAM intercellular adhesion molecule, VCAM vascular cell adhesion molecule, DVT deep vein thrombosis, CKD chronic kidney disease, MI myocardial infarction, CAD coronary artery disease

severe sepsis reported in the study by Harrison et al. was $27.87 \%$ (95 \% CI: 27.52, 28.24) [11] per hospitalisation. The incidence of community-acquired severe sepsis (per hospitalisation) was higher compared to healthcareassociated severe sepsis (5.75 \% vs. $2.37 \%$ ) [50].

Septic shock The incidence estimates for septic shock reported in two studies were 31 (95\% CI: 27, 36) [46] and 9 (95 \% CI: 6, 13) [42] per 100,000 population per year.

\section{Associations between various factors and the occurrence of sepsis}

Two cohort [36, 47] and 4 case-control studies [39, 43-45] contributed relevant data. The associations between socio-demographic factors and COS are provided in Table 4.

Age One prospective cohort study indicated an increased risk of non-severe sepsis with older age ( $\geq 75$ years vs. $45-$
54 years; OR ${ }_{\text {crude }}=3.87,95 \%$ CI: $2.80,5.35$ ) [36]. In contrast, the cohort study by Ginde et al., showed no such evidence ( $\geq 65$ years vs. $<65$ years; OR adjusted $=1.00,95 \%$ CI: $0.52,1.90)$ [47]. One case-control study showed older age ( $\geq 85$ years vs. $15-64$ years) to be associated with an increased risk of all sepsis (OR adjusted $=6.02,95 \%$ CI: 5.09, 7.12), non-severe sepsis ( $\mathrm{OR}$ adjusted $=3.66,95 \% \mathrm{CI}: 2.74$, 4.88 ), and severe sepsis ( $\mathrm{OR}$ adjusted $=7.84,95 \% \mathrm{CI}$ : 6.38, 9.63) [43].

Sex One prospective cohort (the REGARDS-sepsis) study found a significantly increased risk of non-severe sepsis in men compared to women ( HRR crude $=1.30$, $95 \%$ CI: 1.15, 1.48) [36]. In the other cohort study, the risk of severe sepsis in men was not significantly different from that in women ( $\mathrm{OR}$ adjusted $=1.13,95 \% \mathrm{CI}$ : $0.62,2.00$ ) [47]. One case-control study [43] showed no significant difference between men and women in risk for all (OR adjusted $=1.01,95 \% \mathrm{CI}$ : 0.91, 1.11) or severe sepsis $(\mathrm{OR}$ adjusted $=1.07,95 \%$ CI: 0.95, 1.22). 
Table 3 Incidence of community-onset sepsis: cohort studies

\begin{tabular}{|c|c|c|c|c|c|c|c|}
\hline \multirow[t]{2}{*}{ Study ID country } & \multirow{2}{*}{$\begin{array}{l}\text { Cohort and study } \\
\text { characteristics }\end{array}$} & \multirow{2}{*}{$\begin{array}{l}\text { Study design } \\
\text { and duration } \\
\text { of follow-up }\end{array}$} & \multirow{2}{*}{$\begin{array}{l}\text { Type of } \\
\text { sepsis }\end{array}$} & \multicolumn{3}{|c|}{ Incidence - overall (total cohort) } & \multirow{2}{*}{$\begin{array}{l}\text { Methodological } \\
\text { quality (high, } \\
\text { acceptable, low }\end{array}$} \\
\hline & & & & $\begin{array}{l}\mathrm{N} \text { of cases } \\
\text { per } 100,000 \\
\text { population } \\
\text { per year } \\
{[95 \% \mathrm{Cl}]}\end{array}$ & $\begin{array}{l}\text { CIP \% per } \\
\text { hospitalisation } \\
\text { or ED visit per } \\
\text { year }[95 \% \mathrm{Cl}]\end{array}$ & $\begin{array}{l}\text { IDR (N of } \\
\text { cases per } \\
100,000 \mathrm{p}-\mathrm{y}) \\
{[95 \% \mathrm{CI}]}\end{array}$ & \\
\hline \multirow{7}{*}{$\begin{array}{l}\text { Esteban } 2007 \text { [46] } \\
\text { Spain }\end{array}$} & Geographic scope & \multirow{2}{*}{$\begin{array}{l}\text { Prospective } \\
\text { cohort study }\end{array}$} & Non-severe & $367[352,384]$ & $13.28 \%[12.76,13.81]$ & NR & \multirow{7}{*}{$\begin{array}{l}\text { Acceptable } \\
\text { quality }\end{array}$} \\
\hline & City/municipal & & Severe & $104[96,113]$ & $3.76 \%[3.47,4.06]$ & $N R$ & \\
\hline & Setting & \multirow{5}{*}{ FU: 4 months } & Septic shock & $31[27,36]$ & $1.11 \%[0.95,1.28]$ & $N R$ & \\
\hline & ICU, hospital ward & & & & & & \\
\hline & Cohort denominator & & & & & & \\
\hline & $N$ (population) $=573,149$ & & & & & & \\
\hline & $N$ (hospitalisations) $=15,852$ & & & & & & \\
\hline \multirow{7}{*}{$\begin{array}{l}\text { Ginde } 2013 \text { [47] } \\
\text { The USA }\end{array}$} & Geographic scope & \multirow{2}{*}{$\begin{array}{l}\text { Retrospective } \\
\text { cohort study }\end{array}$} & \multirow[t]{7}{*}{ Severe } & \multirow[t]{7}{*}{ NR } & \multirow[t]{7}{*}{$0.40 \%[0.39,0.41]$} & \multirow[t]{7}{*}{ NR } & \multirow[t]{7}{*}{ Low quality } \\
\hline & Nationwide & & & & & & \\
\hline & Setting & \multirow[t]{5}{*}{ FU: 5 years } & & & & & \\
\hline & ED & & & & & & \\
\hline & Cohort denominator & & & & & & \\
\hline & $\mathrm{N}$ (population)=NR & & & & & & \\
\hline & $N$ (all ED visits) $=87,500,000$ & & & & & & \\
\hline \multirow{7}{*}{$\begin{array}{l}\text { Harrison } 2006[11] \\
\text { The UK }\end{array}$} & Geographic scope & \multirow{2}{*}{$\begin{array}{l}\text { Retrospective } \\
\text { cohort study }\end{array}$} & \multirow[t]{7}{*}{ Severe } & \multirow[t]{7}{*}{$66[N R]^{\mu}$} & \multirow[t]{7}{*}{$27.87 \%[27.52,28.24]$} & \multirow[t]{7}{*}{ NR } & \multirow{7}{*}{$\begin{array}{l}\text { Acceptable } \\
\text { quality }\end{array}$} \\
\hline & Nationwide & & & & & & \\
\hline & Setting & FU: 2 years & & & & & \\
\hline & $\begin{array}{l}\text { ICU, combination of ICU with } \\
\text { HDU }\end{array}$ & & & & & & \\
\hline & Cohort denominator & & & & & & \\
\hline & $N$ (population)=NR & & & & & & \\
\hline & $N$ (hospitalisations)=59,527 & & & & & & \\
\hline Henriksen 2015a & Geographic scope & Prospective & All & $727[693,762]$ & $N R$ & $731[697,767]$ & Acceptable \\
\hline & City/municipal & & Non-severe & $264[243,285]$ & $N R$ & $265[245,287]$ & \\
\hline & Setting & FU: 1 year & Severe & $455[428,482]$ & NR & $457[430,485]$ & \\
\hline & ED, ICU & & Septic shock & $9[6,13]$ & NR & $9[6,14]$ & \\
\hline & Cohort denominator & & & & & & \\
\hline & $N($ population $)=235,598$ & & & & & & \\
\hline & $N$ (hospitalisations) $=8,358$ & & & & & & \\
\hline Husak 2010 [48] & Geographic scope & Retrospective & All & $103[\mathrm{NR}]^{\mu}$ & $N R$ & $N R$ & Low quality \\
\hline Canada & Nationwide & conort study & Non-severe & $64[\mathrm{NR}]^{\mu}$ & NR & NR & \\
\hline & Setting & FU: 5 years & Severe & $40[\mathrm{NR}]^{\mu}$ & NR & NR & \\
\hline & ED, ICU, hospital ward & & & & & & \\
\hline & Cohort denominator & & & & & & \\
\hline & $\begin{array}{l}N \text { (population or } \\
\text { hospitalisations)=NR }\end{array}$ & & & & & & \\
\hline Nygard 2014 [49] & Geographic scope & Prospective & Severe & $50[\mathrm{NR}]^{\mu}$ & $0.22 \%[N R]^{\mu}$ & NR & Low quality \\
\hline & City/municipal & contritstuay & & & & & \\
\hline & Setting & FU: 1 year & & & & & \\
\hline & $\begin{array}{l}\text { ED, ICU, HDU, } \\
\text { combination of ICU with HDU }\end{array}$ & & & & & & \\
\hline
\end{tabular}


Table 3 Incidence of community-onset sepsis: cohort studies (Continued)

\begin{tabular}{|c|c|c|c|c|c|c|c|}
\hline & Cohort denominator & & & & & & \\
\hline & $\begin{array}{l}\mathrm{N} \text { (population or } \\
\text { hospitalisations)=NR }\end{array}$ & & & & & & \\
\hline \multirow{7}{*}{$\begin{array}{l}\text { Page } 2015 \text { [50] } \\
\text { The USA }\end{array}$} & Geographic scope & \multirow{2}{*}{$\begin{array}{l}\text { Retrospective } \\
\text { cohort study }\end{array}$} & \multirow[t]{7}{*}{ Severe } & \multirow[t]{7}{*}{ NR } & CA-SS & \multirow[t]{7}{*}{ NR } & \multirow[t]{7}{*}{ Low quality } \\
\hline & Nationwide & & & & $5.75 \%[5.72,5.77]$ & & \\
\hline & Setting & \multirow[t]{5}{*}{ FU: 1 year } & & & HCA-SS & & \\
\hline & NR & & & & $2.37 \%[2.35,2.38]$ & & \\
\hline & Cohort denominator & & & & & & \\
\hline & $N$ (population) $=N R$ & & & & & & \\
\hline & $N$ (hospitalisations)=3,355,753 & & & & & & \\
\hline \multirow{7}{*}{$\begin{array}{l}\text { Wang } 2012 \text { [36] } \\
\text { REGARDS-sepsis } \\
\text { cohort study } \\
\text { 2012-2015 }\end{array}$} & Geographic scope & \multirow{2}{*}{$\begin{array}{l}\text { Prospective } \\
\text { cohort study }\end{array}$} & \multirow[t]{7}{*}{ Non-severe } & \multirow[t]{7}{*}{$514[489,539]$} & \multirow[t]{7}{*}{ NA } & \multirow[t]{7}{*}{$800[760,840]$} & \multirow{7}{*}{$\begin{array}{l}\text { Acceptable } \\
\text { quality }\end{array}$} \\
\hline & Nationwide & & & & & & \\
\hline & Setting & \multirow[t]{5}{*}{ FU: 9-10 years } & & & & & \\
\hline & Hospital ward, ED & & & & & & \\
\hline & Cohort denominator & & & & & & \\
\hline & $N($ population) $=30,239$ & & & & & & \\
\hline & $N$ (hospitalisations) $=N R$ & & & & & & \\
\hline \multirow[t]{7}{*}{$\begin{array}{l}\text { Seymour } 2012 \text { [51] } \\
\text { The USA }\end{array}$} & Geographic scope & \multirow[t]{2}{*}{$\begin{array}{l}\text { Retrospective } \\
\text { cohort study }\end{array}$} & \multirow[t]{7}{*}{ Severe } & \multirow[t]{7}{*}{ NR } & $\begin{array}{l}\text { Entire 10-year } \\
\text { cohort }\end{array}$ & \multirow[t]{7}{*}{ NR } & \multirow[t]{7}{*}{ Low quality } \\
\hline & Regional (within-State) & & & & $3.25 \%[3.20,3.31]$ & & \\
\hline & Setting & \multirow[t]{5}{*}{ FU: 10 years } & & & One-year cohort & & \\
\hline & $\begin{array}{l}\text { Pre-hospital emergency } \\
\text { medical services }\end{array}$ & & & & $4.93 \%[4.73,5.13]$ & & \\
\hline & Cohort denominator & & & & & & \\
\hline & $N($ population) $=N R$ & & & & & & \\
\hline & $\begin{array}{l}N \text { (emergency } \\
\text { encounters) }=407,176\end{array}$ & & & & & & \\
\hline \multirow{7}{*}{$\begin{array}{l}\text { Wang } 2007 \text { [52] } \\
\text { The USA }\end{array}$} & Geographic scope & \multirow{2}{*}{$\begin{array}{l}\text { Retrospective } \\
\text { cohort study }\end{array}$} & \multirow[t]{7}{*}{ Severe } & \multirow[t]{7}{*}{ NR } & \multirow[t]{7}{*}{$0.69 \%[0.61,0.77]$} & \multirow[t]{7}{*}{ NR } & \multirow[t]{7}{*}{ Low quality } \\
\hline & Nationwide & & & & & & \\
\hline & Setting & \multirow[t]{5}{*}{ FU: 4 years } & & & & & \\
\hline & ED & & & & & & \\
\hline & Cohort denominator & & & & & & \\
\hline & $\mathrm{N}$ (population)=NR & & & & & & \\
\hline & $N(E D$ visits) $=82,883,000$ & & & & & & \\
\hline
\end{tabular}

CIP cumulative incidence proportion, IDR incidence density rate, HR hazard rate, $n / N$ number, $p$-y person-years, $95 \%$ CI 95 percent confidence interval; $R E G A R D S$ Reasons for Geographic And Racial Differences in Stroke, FU follow-up, ED emergency department, NA not applicable; NR not reported, ICU intensive care unit, $H D U$ high dependence unit, CA-SS community-acquired severe sepsis, HCA-SS healthcare-acquired severe sepsis

${ }^{\mu} 95 \%$ Cls cannot be calculated, due to the lack of denominator reported

${ }^{\beta}$ REGARDS-sepsis cohort study publications [32-38, 40,41]

Race/ethnicity The effect of race was evaluated in two cohort studies. In the first study, the risk of severe sepsis in Black (OR adjusted $=1.30,95 \%$ CI: 0.62, $2.60)$ or Hispanic (OR adjusted $=0.63,95 \%$ CI: 0.23 , 1.70) participants did not significantly differ from the risk in White participants [47]. The second study however showed White participants to be at a significantly higher risk for non-severe sepsis compared to Black participants (HRR adjusted $=1.56,95 \%$ CI: 1.38 , 1.75) [36].
Education One cohort study reported the risk of sepsis by levels of education and found that lower levels of education were associated with an increased risk of nonsevere sepsis (<high school vs. $\geq$ college; $H R R$ crude $=1.88$, 95 \% CI: 1.54, 2.29) [36].

Nursing home residence One retrospective cohort study found a significant association between nursing home residence and risk of severe sepsis (residence vs. no residence; $\left.\mathrm{OR}_{\text {adjusted }}=2.60,95 \% \mathrm{CI}: 1.20,5.60\right)$ [47]. 
Table 4 Associations between socio-demographic factors and community-onset sepsis: cohort and case-control studies

\begin{tabular}{|c|c|c|c|c|c|c|c|}
\hline $\begin{array}{l}\text { Study ID } \\
\text { country }\end{array}$ & $\begin{array}{l}\text { Geographic } \\
\text { scope and } \\
\text { setting }\end{array}$ & $\begin{array}{l}\text { Study design } \\
\text { Sample size N }\end{array}$ & $\begin{array}{l}\text { Type } \\
\text { of sepsis }\end{array}$ & $\begin{array}{l}\text { Risk factor } \\
\text { (reference and } \\
\text { exposure groups) }\end{array}$ & $\begin{array}{l}\text { Summary measure } \\
\text { of association } \\
\text { (exposure vs. } \\
\text { reference group) } \\
95 \% \mathrm{Cl}\end{array}$ & Covariates adjusted for & $\begin{array}{l}\text { Methodologica } \\
\text { quality }\end{array}$ \\
\hline
\end{tabular}

\section{Age (years)}

Ginde 2013 [47] Nationwide The USA

ED

Retrospective cohort Severe $\quad<65$ study

$N$ (cohort baseline -

all $E D$ visits $)=$ $87,500,000$

\begin{tabular}{|c|c|c|c|c|}
\hline \multirow{4}{*}{$\begin{array}{l}\text { Wang } 2012 \text { [36] } \\
\text { REGARDS-sepsis } \\
\text { cohort study }{ }^{\beta} \\
\text { 2012-2015 } \\
\text { The USA }\end{array}$} & \multirow{3}{*}{$\begin{array}{l}\text { Nationwide } \\
\text { Hospital ward, } \\
\text { ED }\end{array}$} & Prospective cohort & \multirow[t]{4}{*}{ Non-severe } & $45-54$ \\
\hline & & \multirow{3}{*}{$\begin{array}{l}\mathrm{N} \text { (cohort } \\
\text { baseline) }=30,239\end{array}$} & & $55-64$ \\
\hline & & & & $65-74$ \\
\hline & & & & $75 \leq$ \\
\hline \multirow{9}{*}{$\begin{array}{l}\text { Henriksen } \\
\text { 2015b [43] } \\
\text { Denmark }\end{array}$} & City/municipal & Case-control study & \multirow[t]{3}{*}{ All } & $15-64$ \\
\hline & ED, ICU & $N$ (cases) $=1,713$ & & $65-84$ \\
\hline & & $N($ controls $)=227,054$ & & $\geq 85$ \\
\hline & & & \multirow[t]{3}{*}{ Non-severe } & $15-64$ \\
\hline & & & & $65-84$ \\
\hline & & & & $\geq 85$ \\
\hline & & & \multirow[t]{3}{*}{ Severe } & $15-64$ \\
\hline & & & & $65-84$ \\
\hline & & & & $\geq 85$ \\
\hline
\end{tabular}

Sex

Ginde 2013 [47] Nationwide The USA

ED

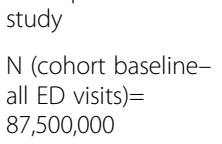

$\begin{array}{ll}\text { Sale } & \text { Mevere } \quad \text { Female } \\ & \text { Male }\end{array}$

$N$ (cohort baseline-

all $E D$ visits)= $87,500,000$

Wang 2012 [36] Nationwide REGARDS-sepsis cohort study $\beta$ 2012-2015 Hospital ward, Prospective cohort Non-severe Black

The USA study analysis

baseline)=30,239
Ref 1.00

$\mathrm{OR}=1.00(0.52,1.90)$

$\mathrm{OR}=0.89(0.76,1.05)$

sex and race/ethnicity

Low quality

Female

Male

Female

Female

Male

Non-Hispanic White Ref 1.00

Non-Hispanic Black $\quad \mathrm{OR}=1.30(0.62,2.60)$

Hispanic

$\mathrm{OR}=0.63(0.23,1.70)$

Other

Ref 1.00

$\mathrm{HRR}=1.44(1.04,2.00)$

$\operatorname{HRR}=2.29(1.66,3.16)$

$\operatorname{HRR}=3.87(2.80,5.35)$

Ref 1.00

$\mathrm{OR}=3.09(2.75,3.48)$

$\mathrm{OR}=6.02(5.09,7.12)$

Ref 1.00

$\mathrm{OR}=2.15(1.78,2.60)$

$\mathrm{OR}=3.66(2.74,4.88)$

Ref 1.00

$\mathrm{OR}=3.93(3.39,4.56)$

$\mathrm{OR}=7.84(6.38,9.63)$

Ref 1.00

$\mathrm{OR}=1.13(0.62,2.00)$

Ref 1.00

HRR $=1.30(1.15,1.48)$

Not adjusted (crude)

Acceptable quality

Low quality

$\mathrm{OR}=1.01(0.91,1.11)$

Ref 1.00

Ref 1.00

$\mathrm{OR}=1.07(0.95,1.22)$

Age, alcoholism- related conditions, comorbidity, and immunosuppression

See above

See above

Age and sex

Low quality

$\mathrm{OR}=2.40(0.87,6.50)$

Ref 1.00

$\operatorname{HRR}=1.56(1.38,1.75)$

White ncome, tobacco, alcoho use, baseline chronic medical conditions, biomarkers
Acceptable quality 
Table 4 Associations between socio-demographic factors and community-onset sepsis: cohort and case-control studies (Continued)

\begin{tabular}{|c|c|c|c|c|c|c|c|}
\hline \multicolumn{8}{|l|}{ Education } \\
\hline $\begin{array}{l}\text { Wang } 2012 \text { [36] } \\
\text { REGARDS-sepsis } \\
\text { cohort study }{ }^{\beta} \\
\text { 2012-2015 } \\
\text { The USA }\end{array}$ & $\begin{array}{l}\text { Nationwide } \\
\text { Hospital ward, } \\
\text { ED }\end{array}$ & $\begin{array}{l}\text { Prospective cohort } \\
\text { study analysis } \\
\mathrm{N} \text { (cohort } \\
\text { baseline) }=30,239\end{array}$ & Non-severe & $\begin{array}{l}\geq \text { College } \\
\text { Some college } \\
\text { High school } \\
<\text { High school }\end{array}$ & $\begin{array}{l}\text { Ref } 1.00 \\
H R R=1.41 \quad(1.19,1.67) \\
H R R=1.52(1.28,1.80) \\
H R R=1.88(1.54,2.29)\end{array}$ & Not adjusted (crude) & $\begin{array}{l}\text { Acceptable } \\
\text { quality }\end{array}$ \\
\hline $\begin{array}{l}\text { Ginde } 2013 \text { [47] } \\
\text { The USA }\end{array}$ & $\begin{array}{l}\text { Nationwide } \\
\text { ED }\end{array}$ & $\begin{array}{l}\text { Retrospective } \\
\text { cohort study } \\
\mathrm{N} \text { (cohort baseline) } \\
=87,500,000\end{array}$ & Severe & $\begin{array}{l}\text { No } \\
\text { Yes }\end{array}$ & $\begin{array}{l}\text { Ref } 1.00 \\
O R=2.60(1.20,5.60)\end{array}$ & Age, sex and race/ethnicity & Low quality \\
\hline
\end{tabular}

NR not reported, ICU intensive care unit, HDU high dependence unit; ED emergency department, $95 \%$ CI 95 percent confidence interval, REGARDS Reasons for Geographic And Racial Differences in Stroke, Ref reference group, OR odds ratio, HRR hazard rate ratio, NSAID non-steroidal anti-inflammatory drug, CKD chronic kidney disease, IL-6 interleukin-6, TNF- $a$ tumor necrosis factor alpha, ICAM intercellular adhesion molecule, VCAM vascular cell adhesion molecule, PSS perceived stress scale, SD standard deviation, Q1-4 dietary intake quartile scores

${ }^{\beta}$ REGARDS-sepsis cohort study publications [32-38, 40,41]

Other factors Associations for anthropometric measures, life-style, clinical factors, medication use, and serum biomarkers are provided in Additional file 4 (Table S3).

One prospective cohort study showed no evidence of significant association between BMI groups in relation to the risk of non-severe sepsis $\left(\geq 40 \mathrm{~kg} / \mathrm{m}^{2}\right.$ vs. $<24.9 \mathrm{~kg} /$ $\mathrm{m}^{2}$; HRR adjusted $=1.14,95 \%$ CI: $\left.0.81,1.62\right)$ [36]. The same study however, showed an increased risk for nonsevere sepsis among current $(\mathrm{HRR}$ crude $=1.85,95 \% \mathrm{CI}$ : $1.54,2.22)$ and past tobacco smokers (HRR crude $=1.64$, 95 \% CI: 1.42, 1.88) compared to never smokers. Moderate alcohol use compared to no alcohol was associated with a reduced risk of non-severe sepsis (HRR crude $=0.78,95 \%$ CI: 0.67, 0.89) [36]. Participants reporting low levels of exercise (i.e., none) were at increased risk of non-severe sepsis compared to those with high levels of exercise ( $\geq 4$ times per week; HRR adjusted $=1.33,95 \%$ CI: 1.13, 1.56).

One case-control and one cohort study demonstrated that people with diabetes had an increased risk for all sepsis (OR adjusted $=1.82,95 \%$ CI: $1.57,2.12)$ [43] and non-severe sepsis (HRR adjusted $=1.78,95 \% \mathrm{CI}$ : 1.53 , 2.07) [36]. Moreover, these two studies reported significantly elevated risk of sepsis for patients with various clinical conditions or disorders (e.g., immunosuppression, renal, psychotic, gastrointestinal, neurologic, cardiovascular disease, cancer, lung disease, deep vein thrombosis, stroke, atrial fibrillation) [36, 43].

\section{Discussion}

This systematic review summarised evidence on the burden of COS in terms of incidence and risk factors from 14 studies.

\section{Incidence of COS}

\section{Major findings}

The annual population-based incidence rates (\# of cases per 100,000 population), as reported in the cohort studies of low to acceptable quality, varied widely for non-severe sepsis (range: 64-514), severe sepsis (range: 40-455), and septic shock (range: 9-31). These results confirm sepsis as a substantial health problem, but underline the uncertainty in the precise burden of this condition. The variability in estimates could be due to differences in the underlying risk for sepsis, data sources, ICD-9/10 coding practices, sepsis definition criteria, and statistical methods of incidence estimation (e.g., choice of denominators, dealing with incomplete outcome data).

It has been shown that different ICD-9/10 coding practices (e.g., methods by Angus [3], Dombrovskiy [54], and Martin [4]) used for severe sepsis cases alone may lead to variable incidence estimates [28, 55-57]. Also, there has been confusion in distinguishing bacteraemia, septicaemia, and severe sepsis which are distinct clinical conditions $[13,58-60]$. The use of different data sources may also have contributed to this variation. The use of discharge diagnoses and different ICD codes have been shown to produce variable estimates with mostly low sensitivity and high specificity for correct identification of sepsis [13]. Similarly, another study estimated that discharge diagnoses had a high specificity (median: $98.5 \%$ ) and poor sensitivity (median: $42.4 \%$ ) for detecting true cases of sepsis, thereby leading to misclassification and underdiagnosis of sepsis [57]. The study by Wang et al. [18] corroborated these findings on the sample of community-dwelling adults at risk for developing $\operatorname{COS}$ and found that the use of discharge databases was highly specific and poorly sensitive for detecting COS (94.6\% and $27.6 \%$, respectively). Although more 
resource-intensive, the utilisation of medical charts allows to review physiologic and laboratory measurements which then may be linked to an underlying infectious pathogen with more certainty. Also, discharge databases unlike medical records do not include the necessary information needed to distinguish community-acquired and hospitalacquired forms of sepsis [18].

The processes occurring over time such as population aging, improvement in detection of sepsis, increased use of immunosuppressive therapy, transplantation, and invasive procedures may also explain the observed variation in sepsis incidence [61]. There is also evidence for changes in the coding and definitions used for sepsis over time. Rhee and colleagues assessed longitudinal data for the annual sensitivity and incidence of discharge ICD-9-CM codes for organ dysfunction (severe sepsis) against clinical criteria [60], and found that from 2005 to 2013, the sensitivity of hospital discharge codes for detecting hospitalisations with severe sepsis had gradually increased (i.e., they have become more inclusive), while clinical thresholds used for defining organ dysfunction had decreased (i.e., they have become less restrictive). The authors concluded that these changes may at least partially explain the increased incidence of severe sepsis over time $[60,62]$. To further explore if the observed trends in sepsis incidence have been influenced by the choice of principal or secondary diagnosis codes, Walkey and colleagues [63] using the US population-based sample of hospitalisation claims for sepsis and specific sources of infection (e.g., pneumonia, urinary tract infection, bacteraemia), calculated annual age-standardised hospitalisation rates for sepsis or infections in 2003-2009. The study showed increasing incidence trends for both sepsis (used as principal diagnosis) and infection requiring mechanical ventilation, with the former rising at a greater rate.

The between-study variation in the definitions and methods for identifying and separating community-onset from hospital-acquired sepsis may have also resulted in different degrees of misclassification of sepsis cases, thereby leading to additional variation in the incidence of sepsis.

\section{Strengths and limitations of the evidence}

Currently, there is great uncertainty across the methods of diagnosis and identification of sepsis. Different ICD9/10 coding practices yield different estimates of true incidence, and there is no consensus as to which method is more valid in correctly identifying sepsis cases.

The incidence of sepsis reported in 10 cohort studies warrants a cautious interpretation. Specifically, 6 studies were of low [47-52], while the remaining 4 studies were of acceptable methodological quality [11, 36, 42, 46].

The findings from three studies of acceptable quality may have limited applicability to the overall UK population. For example, the annual incidence of nonsevere sepsis (514 per 100,000) reported in the cohort study by Wang et al. [36] was dominated by high risk populations (e.g., $60 \%$ of the sample was 60 years or older). The study by Henriksen and colleagues [42], reporting the annual incidence of non-severe sepsis (264 cases per 100,000) was based on a single universitybased hospital, and the rates observed may not be applicable to a wider general population. Similarly, the study by Esteban and colleagues, which also reported the annual incidence of non-severe sepsis (264 cases per $100,000)$ covered only one small metropolitan area of Spain and the study cohort had a short follow-up (4 months) [46].

\section{Consistency of findings}

This review could not identify another systematic review of COS in order to directly assess the consistency of findings. Incidence rates of sepsis (regardless of the place of acquisition) have been reported in several primary studies $[3,4,7-9,28,55,64]$ and reviews $[2,10,13,58$, 59, 65-67].

Most of the reported evidence pertains to the nationwide and regional incidence rates of severe sepsis rather than non-severe sepsis. For example, a recent study which used an administrative data from $20 \%$ of US hospitals compared the incidence rates of severe sepsis using four methods of case ascertainment. Depending on the method used, the incidence of severe sepsis varied from 300 to 1,031 cases per 100,000 population per year. In their cohort study, Karlsson and colleagues reported an incidence of 38 cases of severe sepsis per 100,000 population per year [64]. An earlier study, based on the 1995 US hospital discharge records reported an estimate of 300 cases of severe sepsis per 100,000 US population per year [3]. According to the Martin et al. study, in 2000, the annual incidence of sepsis in the US was estimated to be about 240 cases per 100,000 population [4].

In one recent systematic review [66], the pooled incidence rates restricted to the 2005-2015 years for sepsis and severe sepsis were 437 (95\% CI: 334, 571; $\tau=0.38$ ) and 270 (95\% CI: 176, 412; $\tau=0.60)$ per 100,000 population, respectively.

In general, the estimates of sepsis incidence and the corresponding variability observed in this review were consistent with those of other studies and reviews.

\section{Risk factors of COS \\ Major findings}

Overall, the limited amount of evidence from studies of low to acceptable quality suggested a significantly increased risk of sepsis (non-severe or severe) in association with older age, Caucasian race, lower education, 
greater waist circumference, nursing home residence, tobacco use, physical inactivity, and various chronic clinical conditions. Evidence for sex, body mass index, alcohol use, statin/non-steroidal anti-inflammatory drug use, and selected endothelial inflammation biomarkers was inconsistent or inconclusive.

\section{Strengths and limitations of the evidence}

The evidence on risk factors for COS was sparse and based mostly on studies of low methodological quality. Therefore, caution should be exercised when interpreting these results until more definitive evidence is available. Several factors such as selection bias, residual confounding, exposure/outcome measurement misclassification, and multiple testing (i.e., type-I error) could have accounted for some of the observed associations. Of the 4 case-control studies, the control series in 3 studies were non-sepsis cases hospitalised for infections or non-specified medical conditions [39, 44, 45]. The controls used in the Henriksen et al. study were true non-cases [43]. The use of hospital controls is prone to selection bias if their exposure distribution is not representative of that in the base population that gave rise to cases [68]. For some studies, it was not clear if the same exclusion criteria had been applied to cases and controls. The use of different exclusion criteria may lead to biased effect estimates for the reported risk factors of sepsis [68].

\section{Consistency of findings}

The findings of this review on sex and race are not consistent with those of recent studies not restricted to COS. These studies report sex and racial disparities by showing increased risk of sepsis among males (vs. females) and non-Caucasians (vs. Caucasians) [4, 69, 70]. In our review, one study corroborated these findings and indicated that men were at higher risk for sepsis compared to women [36], but two other studies showed no such evidence [43, 47]. Regarding the effect of race, one included in the review study indicated that Caucasians compared to non-Caucasians were at higher risk of sepsis $[33,36]$ while another showed no significant difference between the two groups [47]. It is not clear whether these discrepancies were due to the distinct associations applicable to COS, differences in the population at risk, or sepsis coding practices across studies.

In agreement with previous research $[10,59]$, our review also found that older age and the presence of clinical chronic conditions are associated with an increased risk for sepsis. This included clinical conditions that are known to impair the human immune system, making the patient more susceptible to various types of infection, among them sepsis.

\section{Strengths and limitations of the review}

This is the first systematic review of recent evidence on the incidence and risk factors of COS. This review was restricted to the evidence analysed in 2002 or later when specific ICD-9 coding for non-severe sepsis (995.91), severe sepsis (995.92), and septic shock (785.52) were introduced [28]. The authors a priori operationalised all methodological steps of this review.

There are several limitations to be acknowledged. First of all, studies that used pre-2002 study data were excluded given the changes in definition/coding practices, dynamic nature of sepsis incidence, and evolution of associated pathogens. Although the restriction by date limits the comprehensiveness of evidence and precision of the review findings, we believe that the pre2002 evidence would not reflect the current context of sepsis accurately in light of the changes in sepsis epidemiology. Although non-English publications were not included, to the best of our knowledge, we are not aware of any empirical evidence showing the effects of language bias on the incidence of sepsis. We also excluded conference abstracts because they do not provide sufficient information to distinguish COS from other types of sepsis. The sparsity of evidence did not allow to explore the extent of publication bias. And finally, the quality assessment tool for cohort studies may not have been equally applicable to exposure and non-exposure cohort studies. Due to poor reporting of publications and subjective nature of study quality assessment tools in general, some misclassification in quality ratings cannot be ruled out.

\section{Future research recommendations}

Future research recommendations according to the PICOTS (Population, Intervention, Comparator, Outcome, Timing, and Setting) framework along with the limitations in evidence are provided as follows:

\section{Population and Setting}

Limitation(s) There is little evidence on the burden of COS from nation-wide population-based cohort studies. Most of the included cohort studies were hospitalbased, covered limited geographic areas, or recruited high-risk subgroups and three of the four included casecontrol studies utilised non-sepsis cases (i.e., hospitalbased controls) as controls which may have led to underestimated associations between the risk factors and sepsis.

Recommendation(s) More evidence is warranted from well conducted population-based prospective cohort studies with samples representative of any given general population. These studies would ideally consist of well-defined cohorts of participants free of sepsis at 
baseline. Future case-control studies would ideally include random samples of population-based controls from the same source population which gave rise to sepsis cases.

Intervention and Comparator (exposure, risk factor groups) Limitation(s) Due to poor reporting, for most of the included studies it was not clear if the methods of exposure measurement were valid. Misclassification of exposure status may have biased the observed effect estimates for risk factors of sepsis in any direction. Moreover, the problem of multiple testing for various risk factors may have led to type-I error (i.e., spurious statistically significant results).

Recommendation(s) Future studies should ideally use standard and validated methods of exposure measurement. Better reporting of these methodologies used would facilitate the methodological or risk of bias assessment for researchers and practitioners involved in evidence synthesis.

\section{Outcome}

Limitation(s) The estimates of COS incidence were highly variable perhaps owing to well documented differences or changes in sepsis definition, diagnosis, and ascertainment practices across studies.

Recommendation(s) The use of accurate and standard methodology for sepsis surveillance and ascertainment would ensure more valid estimation and comparability of sepsis incidence and risk factors across studies.

\section{Timing}

Limitation(s) About $40 \%$ of the included cohort studies had a follow-up shorter than 2 years. Some of the estimates of incidence may have been subject to seasonal variation or any other extraneous factor.

Recommendation(s) Studies with longer follow-up are needed to improve stability and precision around sepsis incidence estimates

\section{Policy implications}

Improvements in the accuracy and consistency of sepsis definition, diagnostic criteria, and standardisation of methods for ascertainment of sepsis are prerequisites for assessing the public health burden of sepsis reliably in order to adequately inform public facing health campaigns. A robust monitoring system to support evaluation of any future interventions will require the development of unbiased national surveillance. More studies investigating specific causative pathogens of sepsis (e.g., meningococcal sepsis) with the corresponding incidence, and the related risk factors would provide additional evidence needed to inform the policy for public facing health campaigns targeted to specific causes of sepsis. The findings of this review will help to inform recommendations in relation to public facing campaigns targeting timely presentation and diagnosis of sepsis in the community and provide a policy for future public health planning.

\section{Conclusion}

This review found a highly variable annual populationbased incidence of non-severe (range: 64-514 per 100,000 ) and severe COS (range: $40-455$ per 100,000 ), likely due to different definitions and ascertainment methods of sepsis across included studies. Limited evidence identified several risk factors for sepsis (e.g., older age, lower education, presence of clinical conditions, nursing home residence, and lower levels of physical activity).

Timeliness and accuracy of diagnosis of sepsis are both crucial aspects for improving the patient's outcome. It is hoped that findings of this review will inform recommendations on public facing campaigns to improve timely presentation and diagnosis of sepsis in the community and provide a basis for future research and policy for public health planning.

\section{Additional files}

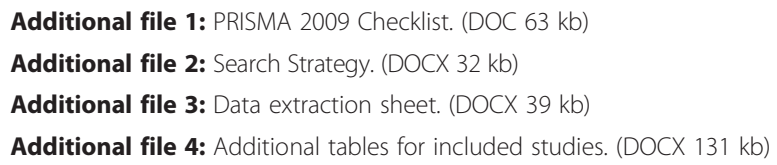

Abbreviations

PHE: Public Health England; ICU: intensive-care unit; ICD-9/10: International Classification of Diseases, $9^{\text {th }} / 10^{\text {th }}$ revision; SIRS: Systemic Inflammatory Response Syndrome; ACCP: American College of Chest Physicians; SCCM: Society of Critical Care Medicine; HIV: Human Immunodeficiency Virus; UK: United Kingdom; USA: United States of America; PRISMA: Preferred Reporting Items for Systematic review and Meta-Analysis; REGARDS: Reasons for Geographic And Racial Differences in Stroke; COS: Community-Onset Sepsis; SIGN: Scottish Intercollegiate Guidelines Network; CIP: Cumulative Incidence Proportion; IDR: Incidence Density Rate; OR: Odds Ratio; HRR: Hazard Rate Ratio; ED: Emergency Department; NSAIDs: Non-Steroidal Anti-Inflammatory Drugs; NA: Not Applicable; NR: Nor Reported; CKD: Chronic Kidney Disease; IL-6: Interleukin-6; TNF-a: Tumour Necrosis Factor Alpha; ICAM: Intercellular Adhesion Molecule; VCAM: Vascular Cell Adhesion Molecule; SD: Standard Deviation; PSS: Perceived Stress Scale; DVT: Deep Vein Thrombosis; CVD: Cardiovascular Disease; MI: Myocardial Infarction; CAD: Coronary Artery Disease; AIDS: Acquired Immunodeficiency Syndrome; Gl: Gastrointestinal.

\section{Competing interests}

The authors declare that they have no competing interests. The funder, the Public Health England identified the topic and provided an initial outline specification for their research needs, but did not play any role at any stage of the manuscript development. 


\section{Authors' contributions}

AT contributed to the topic refinement, formulation of research question, review design, study selection forms, data extraction sheets, plan of analysis, draft of the protocol; PR designed the search strategy, provided database management, and conducted literature search/handled the bibliography; $\mathrm{NMCC}$ contributed to the topic refinement, formulation of research question, review design, plan of analysis, and feedback on the draft protocol; FS contributed to the study screening process; RC and JC participated in the data extraction process. All authors read and approved the final manuscript.

\section{Acknowledgments}

The Public Health England supports the Communicable Disease Control Epidemiology and Evidence unit at Warwick Medical School, University of Warwick which employs Alexander Tsertsvadze, Pam Royle and Noel McCarthy. Rebecca Crosby and Jennifer Cooper were supported by the National Institute of Health Research (NIHR) Collaboration for Leadership in Applied Health Research and Care (CLAHRC) West Midlands' initiative. This report presents independent research and the views expressed are those of the author(s) and not necessarily those of the National Health Service (NHS), the NIHR or the Department of Health.

\section{Author details}

'Communicable Disease Control Epidemiology and Evidence; Populations, Evidence and Technologies, Division of Health Sciences, Warwick Medical School, University of Warwick, Coventry CV4 7AL, UK. ${ }^{2}$ Division of Health Sciences, Warwick Medical School, University of Warwick, Coventry CV4 7AL, UK. ${ }^{3} \mathrm{NIHR}$ Health Protections Research Unit in Gastrointestinal Infections, University of Oxford, Oxford, UK.

\section{Received: 11 December 2015 Accepted: 12 April 2016} Published online: 18 May 2016

\section{References}

1. Levy MM, Fink MP, Marshall JC, Abraham E, Angus D, Cook D, et al. 2001 SCCM/ESICM/ACCP/ATS/SIS International Sepsis Definitions Conference. Crit Care Med. 2003;31(4):1250-6. doi:10.1097/01.CCM.0000050454.01978.3B.

2. Moss M. Epidemiology of sepsis: race, sex, and chronic alcohol abuse. Clin Infect Dis. 2005:41 Suppl 7:\$490-7. doi:10.1086/432003.

3. Angus DC, Linde-Zwirble WT, Lidicker J, Clermont G, Carcillo J, Pinsky MR. Epidemiology of severe sepsis in the United States: analysis of incidence, outcome, and associated costs of care. Crit Care Med. 2001;29(7):1303-10.

4. Martin GS, Mannino DM, Eaton S, Moss M. The epidemiology of sepsis in the United States from 1979 through 2000. N Engl J Med. 2003;348(16): 1546-54. doi:10.1056/NEJMoa022139.

5. Vincent JL, Sakr Y, Sprung CL, Ranieri VM, Reinhart K, Gerlach H, et al. Sepsis in European intensive care units: results of the SOAP study. Crit Care Med. 2006:34(2):344-53.

6. Daniels R. The incidence, mortality and economic burden of sepsis. In: NHS Evid Emerg \& Urgent Care. 2009.

7. Padkin A, Goldfrad C, Brady AR, Young D, Black N, Rowan K. Epidemiology of severe sepsis occurring in the first 24 hrs in intensive care units in England, Wales, and Northern Ireland. Crit Care Med. 2003;31(9):2332-8. doi:10.1097/01.CCM.0000085141.75513.2B.

8. Brun-Buisson C, Meshaka P, Pinton P, Vallet B. EPISEPSIS: a reappraisal of the epidemiology and outcome of severe sepsis in French intensive care units. Intensive Care Med. 2004;30(4):580-8. doi:10.1007/s00134-003-2121-4.

9. Finfer S, Bellomo R, Lipman J, French C, Dobb G, Myburgh J. Adultpopulation incidence of severe sepsis in Australian and New Zealand intensive care units. Intensive Care Med. 2004;30(4):589-96. doi:10.1007/ s00134-004-2157-0.

10. Martin GS. Sepsis, severe sepsis and septic shock: changes in incidence, pathogens and outcomes. Expert Rev Anti-Infect Ther. 2012;10(6):701-6. doi:10.1586/eri.12.50

11. Harrison DA, Welch CA, Eddleston JM. The epidemiology of severe sepsis in England, Wales and Northern Ireland, 1996 to 2004: secondary analysis of a high quality clinical database, the ICNARC Case Mix Programme Database. Crit Care. 2006;10(2):R42. doi:10.1186/cc4854.

12. Hall MJ, Williams SN, DeFrances CJ, Golosinskiy A. Inpatient care for septicemia or sepsis: a challenge for patients and hospitals. NCHS Data Brief. 2011;62:1-8.
13. Cohen J, Vincent JL, Adhikari NK, Machado FR, Angus DC, Calandra T, et al. Sepsis: a roadmap for future research. Lancet Infect Dis. 2015;15(5):581-614. doi:10.1016/S1473-3099(15)70112-X.

14. Rhee C, Gohil S, Klompas M. Regulatory mandates for sepsis care-reasons for caution. N Engl J Med. 2014;370(18):1673-6. doi:10.1056/NEJMp1400276.

15. Bone RC, Balk RA, Cerra FB, Dellinger RP, Fein AM, Knaus WA, et al. Definitions for sepsis and organ failure and guidelines for the use of innovative therapies in sepsis. The ACCP/SCCM Consensus Conference Committee. American College of Chest Physicians/Society of Critical Care Medicine. Chest. 1992;101(6):1644-55.

16. Vincent JL, Opal SM, Marshall JC, Tracey KJ. Sepsis definitions: time for change. Lancet. 2013;381(9868):774-5. doi:10.1016/s0140-6736(12)61815-7.

17. American Thoracic S. Infectious Diseases Society of A. Guidelines for the management of adults with hospital-acquired, ventilator-associated, and healthcare-associated pneumonia. Am J Respir Crit Care Med. 2005;171(4): 388-416. doi:10.1164/rccm.200405-644ST.

18. Wang HE, Addis DR, Donnelly JP, Shapiro NI, Griffin RL, Safford MM, et al. Discharge diagnoses versus medical record review in the identification of community-acquired sepsis. Crit Care. 2015;19:42. doi:10.1186/s13054-015-0771-6.

19. Hoenigl M, Wagner J, Raggam RB, Prueller F, Prattes J, Eigl S, et al. Characteristics of hospital-acquired and community-onset blood stream infections, South-East Austria. PLoS One. 2014;9(8):e104702. doi:10.1371/journal.pone.0104702.

20. Lenz R, Leal JR, Church DL, Gregson DB, Ross T, Laupland KB. The distinct category of healthcare associated bloodstream infections. BMC Infect Dis. 2012;12:85. doi:10.1186/1471-2334-12-85.

21. Diekema DJ, Beekmann SE, Chapin KC, Morel KA, Munson E, Doern GV. Epidemiology and outcome of nosocomial and community-onset bloodstream infection. J Clin Microbiol. 2003:41(8):3655-60.

22. Cardoso T, Almeida M, Friedman ND, Aragao I, Costa-Pereira A, Sarmento AE, et al Classification of healthcare-associated infection: a systematic review 10 years after the first proposal. BMC Med. 2014;12:40. doi:10.1186/1741-7015-12-40.

23. Friedman ND, Kaye KS, Stout JE, McGarry SA, Trivette SL, Briggs JP, et al. Health care-associated bloodstream infections in adults: a reason to change the accepted definition of community-acquired infections. Ann Intern Med. 2002;137(10):791-7.

24. Adrie C, Alberti C, Chaix-Couturier C, Azoulay E, De Lassence A, Cohen Y, et al. Epidemiology and economic evaluation of severe sepsis in France: age, severity, infection site, and place of acquisition (community, hospital, or intensive care unit) as determinants of workload and cost. J Crit Care. 2005:20(1):46-58.

25. Rodriguez-Bano J, Lopez-Prieto MD, Portillo MM, Retamar P, Natera C, Nuno $E$, et al. Epidemiology and clinical features of community-acquired, healthcare-associated and nosocomial bloodstream infections in tertiarycare and community hospitals. Clin Microbiol Infect. 2010;16(9):1408-13. doi:10.1111/j.1469-0691.2009.03089.x.

26. Tsertsvadze A, Royle P, McCarthy N. Community-onset sepsis and its public health burden: protocol of a systematic review. Syst Rev. 2015;4:119. doi:10.1186/s13643-015-0103-6

27. Moher D, Liberati A, Tetzlaff J, Altman DG, Group P. Preferred reporting items for systematic reviews and meta-analyses: the PRISMA statement. Ann Intern Med. 2009;151(4):264-9. W64.

28. Gaieski DF, Edwards JM, Kallan MJ, Carr BG. Benchmarking the incidence and mortality of severe sepsis in the United States. Crit Care Med. 2013; 41(5):1167-74. doi:10.1097/CCM.0b013e31827c09f8.

29. Scottish Intercollegiate Guidelines Network. Checklist 3: Cohort Studies. In SIGN 50: A Guideline Developer's Handbook, Edinburgh. 2008. http://www. sign.ac.uk/methodology/checklists.html. Accessed 19 May 2015.

30. Scottish Intercollegiate Guidelines Network. Checklist 4: Case-control Studies. In SIGN 50: A Guideline Developer's Handbook, Edinburgh. 2008. http://www. sign.ac.uk/methodology/checklists.html. Accessed 19 May 2015.

31. Harder T, Takla A, Rehfuess E, Sanchez-Vivar A, Matysiak-Klose D, Eckmanns T, et al, Evidence-based decision-making in infectious diseases epidemiology, prevention and control: matching research questions to study designs and quality appraisal tools. BMC Med Res Methodol. 2014;14:69. doi:10.1186/1471-2288-14-69.

32. Gutierrez OM, Judd SE, Voeks JH, Carson AP, Safford MM, Shikany JM, et al. Diet patterns and risk of sepsis in community-dwelling adults: a cohort study. BMC Infect Dis. 2015;15:231. doi:10.1186/s12879-015-0981-1.

33. Moore JX, Donnelly JP, Griffin R, Safford MM, Howard G, Baddley J, et al. Black-white racial disparities in sepsis: a prospective analysis of the REasons for Geographic And Racial Differences in Stroke (REGARDS) cohort. Crit Care. 2015;19:279. doi:10.1186/s13054-015-0992-8. 
34. Ojard C, Donnelly JP, Safford MM, Griffin R, Wang HE. Psychosocial stress as a risk factor for sepsis: a population-based cohort study. Psychosom Med. 2015;77(1):93-100.

35. Powell TC, Donnelly JP, Gutierrez OM, Griffin RL, Safford MM, Wang HE. Cystatin $C$ and long term risk of community-acquired sepsis: a populationbased cohort study. BMC Nephrol. 2015;16(1):61.

36. Wang HE, Shapiro NI, Griffin R, Safford MM, Judd S, Howard G. Chronic medical conditions and risk of sepsis. PLoS One. 2012;7(10):e48307. doi:10. 1371/journal.pone.0048307.

37. Wang HE, Griffin R, Judd S, Shapiro NI, Safford MM. Obesity and risk of sepsis: a population-based cohort study. Obesity (Silver Spring, Md). 2013; 21(12):E762-9. doi:10.1002/oby.20468.

38. Wang HE, Shapiro NI, Safford MM, Griffin R, Judd S, Rodgers JB, et al. Highsensitivity C-reactive protein and risk of sepsis. PLoS One. 2013;8(7):e69232 doi:10.1371/journal.pone.0069232.

39. Wang HE, Shapiro NI, Griffin R, Safford MM, Judd S, Howard G. Inflammatory and endothelial activation biomarkers and risk of sepsis: a nested casecontrol study. J Crit Care. 2013;28(5):549-55. doi:10.1016/j.jcrc.2012.11.002.

40. Wang HE, Baddley J, Griffin RL, Judd S, Howard G, Donnelly JP, et al. Physical inactivity and long-term rates of community-acquired sepsis. Prev Med. 2014;65:58-64.

41. Wang HE, Griffin R, Shapiro NI, Howard G, Safford MM. Chronic Statin Use and Long-Term Rates of Sepsis: A Population-Based Cohort Study. J Intensive Care Med. 2014. doi: 10.1177/0885066614550280.

42. Henriksen DP, Laursen CB, Jensen TG, Hallas J, Pedersen C, Lassen AT. Incidence rate of community-acquired sepsis among hospitalized acute medical patients-a population-based survey. Crit Care Med. 2015;43(1):13-21.

43. Henriksen DP, Pottegard A, Laursen CB, Jensen TG, Hallas J, Pedersen C, et al. Risk factors for hospitalization due to community-acquired sepsis a population-based case-control study. PLoS One. 2015;10(4):e0124838. doi:10.1371/journal.pone.0124838.

44. Jovanovich AJ, Ginde AA, Holmen J, Jablonski K, Allyn RL, Kendrick J, et al. Vitamin D level and risk of community-acquired pneumonia and sepsis. Nutrients. 2014;6(6):2196-205.

45. Legras A, Giraudeau B, Jonville-Bera AP, Camus C, Francois B, Runge I, et al. A multicentre case-control study of nonsteroidal anti-inflammatory drugs as a risk factor for severe sepsis and septic shock. Critical Care (London, England). 2009;13(2):R43.

46. Esteban A, Frutos-Vivar F, Ferguson ND, Penuelas O, Lorente JA, Gordo F, et al. Sepsis incidence and outcome: contrasting the intensive care unit with the hospital ward. Crit Care Med. 2007;35(5):1284-9.

47. Ginde AA, Moss M, Shapiro NI, Schwartz RS. Impact of older age and nursing home residence on clinical outcomes of US emergency department visits for severe sepsis. J Crit Care. 2013;28(5):606-11.

48. Husak L, Marcuzzi A, Herring J, Wen E, Yin L, Capan DD, et al. National analysis of sepsis hospitalizations and factors contributing to sepsis in-hospital mortality in Canada. Healthcare Q (Toronto, Ont). 2010;13 Spec No:35-41.

49. Nygard ST, Langeland N, Flaatten HK, Fanebust R, Haugen O, Skrede S. Aetiology, antimicrobial therapy and outcome of patients with community acquired severe sepsis: a prospective study in a Norwegian university hospital. BMC Infect Dis. 2014;14:121.

50. Page DB, Donnelly JP, Wang HE. Community-, Healthcare-, and Hospital-Acquired Severe Sepsis Hospitalizations in the University HealthSystem Consortium. Crit Care Med. 2015;43(9):1945-51. doi:10.1097/ccm.0000000000001164.

51. Seymour CW, Rea TD, Kahn JM, Walkey AJ, Yealy DM, Angus DC. Severe sepsis in pre-hospital emergency care: analysis of incidence, care, and outcome. Am J Respirat Crit Care Med. 2012;186(12):1264-71.

52. Wang HE, Shapiro NI, Angus DC, Yealy DM. National estimates of severe sepsis in United States emergency departments. Crit Care Med. 2007;35(8): 1928-36. doi:10.1097/01.ccm.0000277043.85378.c1.

53. Howard VJ, Cushman M, Pulley L, Gomez CR, Go RC, Prineas RJ, et al. The reasons for geographic and racial differences in stroke study: objectives and design. Neuroepidemiology. 2005;25(3):135-43. doi:10.1159/000086678.

54. Dombrovskiy W, Martin AA, Sunderram J, Paz HL. Rapid increase in hospitalization and mortality rates for severe sepsis in the United States: a trend analysis from 1993 to 2003. Crit Care Med. 2007:35(5):1244-50.

55. Wilhelms SB, Huss FR, Granath G, Sjoberg F. Assessment of incidence of severe sepsis in Sweden using different ways of abstracting International Classification of Diseases codes: difficulties with methods and interpretation of results. Crit Care Med. 2010:38(6):1442-9. doi:10.1097/CCM.0b013e3181de4406.
56. Lagu T, Rothberg MB, Shieh MS, Pekow PS, Steingrub JS, Lindenauer PK. What is the best method for estimating the burden of severe sepsis in the United States? J Crit Care. 2012;27(4):414 e1-9. doi:10.1016/j.jcrc.2012.02.004

57. Jolley RJ, Sawka KJ, Yergens DW, Quan H, Jette N, Doig CJ. Validity of administrative data in recording sepsis: a systematic review. Crit Care. 2015; 19(1):139. doi:10.1186/s13054-015-0847-3.

58. Angus DC, van der Poll T. Severe sepsis and septic shock. N Engl J Med. 2013;369(21):2063. doi:10.1056/NEJMc1312359.

59. Danai P, Martin GS. Epidemiology of sepsis: recent advances. Curr Infect Dis Rep. 2005;7(5):329-34.

60. Rhee C, Murphy MV, Li L, Platt R, Klompas M. Comparison of trends in sepsis incidence and coding using administrative claims versus objective clinical data. Clin Infect Dis. 2015;60(1):88-95. doi:10.1093/cid/ciu750.

61. Mayr FB, Yende S, Angus DC. Epidemiology of severe sepsis. Virulence. 2014 5(1):4-11. doi:10.4161/viru.27372.

62. Rhee C, Murphy MV, Li L, Platt R, Klompas M. Improving documentation and coding for acute organ dysfunction biases estimates of changing sepsis severity and burden: a retrospective study. Crit Care. 2015;19:338. doi:10.1186/s13054-015-1048-9.

63. Walkey AJ, Lagu T, Lindenauer PK. Trends in sepsis and infection sources in the United States. A population-based study. Ann Am Thoracic Soc. 2015; 12(2):216-20. doi:10.1513/AnnalsATS.201411-498BC.

64. Karlsson S, Varpula M, Ruokonen E, Pettila V, Parviainen I, Ala-Kokko TI, et al. Incidence, treatment, and outcome of severe sepsis in ICU-treated adults in Finland: the Finnsepsis study. Intensive Care Med. 2007;33(3):435-43. doi:10.1007/s00134-006-0504-z.

65. Jawad I, Luksic I, Rafnsson SB. Assessing available information on the burden of sepsis: global estimates of incidence, prevalence and mortality. J Global Health. 2012;2(1):010404. doi:10.7189/jogh.02.010404.

66. Fleischmann C, Scherag A, Adhikari NK, Hartog CS, Tsaganos T, Schlattmann $P$ et al. Assessment of global incidence and mortality of hospital-treated sepsis - current estimates and limitations. Am J Respirat Crit Care Med. 2015. doi:10.1164/rccm.201504-07810C.

67. Balk RA. Severe sepsis and septic shock. Definitions, epidemiology, and clinical manifestations. Crit Care Clin. 2000;16(2):179-92.

68. Wacholder S, Silverman DT, McLaughlin JK, Mandel JS. Selection of controls in case-control studies. II. Types of controls. Am J Epidemiol. 1992;135(9):1029-41.

69. Esper AM, Moss M, Lewis CA, Nisbet R, Mannino DM, Martin GS. The role of infection and comorbidity: Factors that influence disparities in sepsis. Crit Care Med. 2006;34(10):2576-82. doi:10.1097/01.CCM.0000239114.50519.0E.

70. Mayr FB, Yende S, Linde-Zwirble WT, Peck-Palmer OM, Barnato AE, Weissfeld $L A$, et al. Infection rate and acute organ dysfunction risk as explanations for racial differences in severe sepsis. JAMA. 2010;303(24):2495-503. doi:10.1001/ jama.2010.851

\section{Submit your next manuscript to BioMed Central and we will help you at every step:}

- We accept pre-submission inquiries

- Our selector tool helps you to find the most relevant journal

- We provide round the clock customer support

- Convenient online submission

- Thorough peer review

- Inclusion in PubMed and all major indexing services

- Maximum visibility for your research

Submit your manuscript at www.biomedcentral.com/submit 